\title{
Asmenybinio ir partinio balsavimo santykio teritorinè diferenciacija 2012 ir 2016 metais. Seimo rinkimų duomenys
}

\author{
Akvilè Vikšraitienė, \\ Rolandas Tučas \\ Vilniaus universitetas, \\ M. K. Čiurlionio g. 27, \\ 03101 Vilnius \\ El. paštas: akvile.strakauskaite@gf.stud.vu.lt; \\ rolandas.tucas@gf.vu.lt
}

Vikšraitienė A., Tučas R. Asmenybinio ir partinio balsavimo santykio teritorinè diferenciacija 2012 ir 2016 metais. Seimo rinkimų duomenys. Geologija. Geografija. T. 5(2). ISSN 2351-7549.

Straipsnyje analizuojama padalinto balsavimo teritorine raiška Lietuvoje. Tyrime naudoti Lietuvos Respublikos Seimo 2012 ir 2016 m. rinkimų duomenys. Tyrimas atliktas vienmandačių rinkimų apygardų ir apylinkių teritorini lygmeniu. Straipsnyje aptariami du klausimai: 1) atlikta 2012 ir 2016 m. Seimo rinkimų palyginamoji geografinè analizé, kurioje vienmandačių apygardų teritoriniu lygmeniu analizuoti partijų ir kandidatu populiarumo kaitos regioniniai aspektai; 2) 2016 m. Seimo rinkimų rezultatų pagrindu apylinkių lygmeniu analizuota padalyto balsavimo raiška centro-periferijos atžvilgiu. Vertinant padalyto balsavimo teritorinę raišką daroma išvada, kad Lietuvoje gana ryškus miestoperiferijos pjūvis. Lietuvos didžiųjų miestų (Vilniaus, Kauno ir Šiaulių) vienmandatėse rinkimų apygardose I ture nugalèjęs kandidatas ir tose pat apygardose pirmavęs jam atstovaujančios partijos sąrašas sutapo santykinai dažniau nei kaimiškose apygardose (išskyrus kai kuriuos Lietuvos regionus). Be to, kai kuriuose mažesnèse Lietuvos savivaldybèse didelę itaką turi žinomos asmenybės, kurių aktyvus dalyvavimas politikoje lemia juos delegavusių partijų santykinai didesnị populiarumą tose pačiose savivaldybèse.

Raktažodžiai: rinkimų (elektorinė) geografija, Seimo rinkimai, padalytas balsavimas, mažoritarinė rinkimų sistema, proporciné rinkimų sistema

\section{IVADAS}

Nuo 1992 m. Lietuvos Respublikos Seimo rinkimuose naudojama viena iš mišrios rinkimų sistemos atmainų - mišri paralelinè rinkimų sistema, kuri dažnai Lietuvos (Jastramskis, 2018a; Morkevičius, 2018) ir užsienio (Sartori, 2001) politologų vertinama kaip viena iš prasčiausių.
G. Sartori, aptardamas Italijos, Rusijos ir Japonijos pavyzdžius, teigè, kad mišri paralelinè sistema sutelkia ne gerąsias, o atvirkščiai - blogąsias abiejų sistemų (mažoritarinès ir proporcinio atstovavimo) savybes (Sartori, 2001). Analizuodami iki $2016 \mathrm{~m}$. Lietuvoje vykusius Seimo rinkimus, rinkejuc atstovaujamumo problematiką, padalyto balsavimo reiškinị, panašias išvadas paskelbe ir 
Lietuvos politologai (Jastramskis, 2018a, 2018b, 2018c; Morkevičius, 2018). Mūsų (šio straipsnio autorių) nuomonè dar griežtesnè - bene dažniausiai minimas mažoritarinès rinkimų sistemos "privalumas“ - teritorinis atstovaujamumas Lietuvoje gali būti vertinamas ir negatyviai (iškraipo rinkejjų lūkesčius ir taip mažina savivaldos svarbą; sukuria prielaidas neskaidriems susitarimams; Seimo nariui trukdo vykdyti tiesiogines jo funkcijas ir pan.), taip iš viso atmetant bet kokius mažoritarinès rinkimų sistemos privalumus. Tuo tarpu vienas iš proporcinio atstovavimo (PA) rinkimų sistemos "trūkumü“ - jos formuojama bei palaikoma fragmentuota partinè sistema gali būti vertinama ir teigiamai (pvz., Lijphart, 1968), nes didina visuomenès grupių atstovaujamumą (proporcingas atstovavimas - nekvestionuojamas "moderniosios demokratijos" privalumas), o jos poveikis vykdomosios valdžios stabilumui bei atskaitingumui nèra toks rimtas trūkumas, kaip ji kartais bando pateikti PA priešininkai (tai straipsnio autorių nuomoné, su kuria galima ir nesutikti).

Šiame straipsnyje aptariama problematika glaudžiai susijusi su mišrios paralelinès rinkimų sistemos nulemtu padalyto balsavimo reiškiniu, kurị gana paviršutiniškai galima suvokti kaip asmenybinio ir partinio balsavimo santykị. Š rezultatų palyginimą vienmandatèse ir daugiamandateje rinkimų apygardose. Pasaulyje gana retai (iš esmès tik kai kuriose Rytų Azijos ir postsovietinio bloko šalyse) naudojamoms mišrioms paralelinėms sistemoms, kurios nuo mišrių kompensacinių (pvz., Bundestago rinkimų sistema Vokietijoje) sistemų skiriasi tuo, kad abu elementai (proporcinio atstovavimo ir mažoritarinis) yra tarpusavyje nesusiję - t. y. „paralelūs" (Krupavičius, Pogorelis, 2004; Jastramskis, 2018a). Mišriose rinkimų sistemose rinkejjas turi du balsus: pirmasis atiduodamas už politinès partijos iškeltą arba nepriklausomą kandidatą, o antrasis - panaudojamas balsuojant už partijos sąrašą, kurị dažnai dar galima ir reitinguoti. Toks „dvilypis“ balsavimas yra palankus padalyto balsavimo (angl. split-ticket voting) (dar vad. „balso suskaidymo“ (angl. vote-spliting) (Ramonaitè, 2014)) reiškiniui, kai rinkejjas rinkimuose daugiamandatèje apygardoje balsuoja už vienos partijos sąrašą, o vienmandatèje apygardoje dèl ìvairiausių priežasčių pasirenka jau kitos partijos (arba nepriklausomą) kandidatą (Plescia, 2016; Morkevičius, 2018).

Asmenybinis balsavimas labiausiai pasireiškia per mažoritarinę (daugumos) rinkimų sistemą - ji reglamentuoja balsavimą ne už pasirinktą partiją, o už asmenybes - kandidatus, kurie yra dažnai tiesiogiai susiję (gyvenę, dirbę ir pan.) su tuo kraštu, kuriame kandidatuoja arba plačiąja prasme visuomeneje yra žinomos ir gerbiamos asmenybès. Mažoritarinès rinkimų sistemos atveju, lyginant su proporcinio atstovavimo, kandidato partiné priklausomybe jau nèra tokia svarbi - gerokai svarbesnès tampa kandidato asmeninès savybės ir kontekstas (pvz., kandidato ryšys su apygarda, kurioje jis kandidatuoja). Tačiau sąsaja su jo partiškumu taip pat išlieka. Viena vertus, rinkejjas dažnai atsižvelgia ł̇ kandidato partinę priklausomybę - tai tampa vienu iš kandidatą apibūdinančių bruožų, kita vertus, vienmandatès apygardos kandidatas turi ittakos partijos sąrašo populiarumui toje apygardoje. Politologinèje literatūroje tokia netiesioginè sąsaja mišriose paralelinèse sistemose tarp vienmandatès kandidato ir jo atstovaujamos partijos sąrašo daugiamandateje apygardoje vadinama „apkrètimo efektu" (angl. contamination effect) (Ferrara ir kt., 2005; Maeda, 2008; Jastramskis, 2018a; Morkevičius, 2018). Šis vienmandatès kandidato ir jam atstovaujančios partijos sąryšis teritoriniu aspektu taip pat analizuojamas šiame tyrime.

Kiek kitaip yra su partiniu balsavimu. Partinis balsavimas remiasi partijos reitingavimu ir tai aiškiausiai atspindi proporcini atstovavimą rinkimų sistemoje. Partiniame balsavime dažniausiai atkreipiamas dèmesys ị partiją, kuriai yra simpatizuojama. Brandžiose demokratijose dažniausiai rinkejjai balsuoja už tas partijas, kurių ideologinès nuostatos ir programiniai siekiai yra artimi jų pažiūroms ir interesams. Kadangi aiškesnių politinių nuostatų turejjimas Lietuvoje susijęs su aukštesniu gyventojų išsilavinimu, o daugiausia aukštesnị išsilavinimą turinčių žmonių gyvena miestuose, tad galima daryti prielaidą, kad partinis balsavimas santykinai labiau priimtinas miestų (ypač didžiųjų) gyventojams. Be to, jis palankesnis mažumoms ar mažiau ịtakingoms (tačiau ne pačioms mažiausioms) partijoms. Tuo tarpu asmenybiniam balsavimui svarbūs teritorinio konteksto efektai (ar kandidatas gimęs, dirbęs 
toje vietoveje, jo socialiniai ryšiai ir kt.) mieste dèl sunykusio jų gyventojų teritorinio bendruomeniškumo turi mažesnès ittakos nei kaimiškose vietovèse. Tačiau būtų klaidinga manyti, kad balsavimas už partijų sąrašus grindžiamas tik rinkèjų ideologinemis nuostatomis ir partijų programų atitikimu jų interesams. Iš tiesų Lietuvos elektorato tyrimai rodo, kad mūsų rinkejjų partinè tapatybė (su kai kuriomis išimtimis - pvz., TS-LKD) išlieka gana silpna, o tai lemia ir nestabilią bei fragmentuotą partinę sistemą (Ramonaite, Jastramskis, 2016b; Jastramskis, 2018b, 2018c; Morkevičius, 2018). Tuo mūsų rinkejjai vis dar gerokai skiriasi nuo brandesnių Vakarų demokratijų rinkejų. Todèl kalbèti apie partinị balsavimą proporcinèje dalyje negalima be išlygų, nes ir čia gana stipriai reiškiasi asmenybinis balsavimas.

Tyrimo tikslas - nustatyti padalyto balsavimo erdvinę raišką centras-periferija teritoriniu pjūviu.

Temos aktualumas. Kaip jau buvo minèta, Lietuvoje Seimo rinkimuose taikoma paralelinè rinkimų sistema, tad tyrimo tema gana aktuali. Prieš porą metų, kai buvo atliekamas šis tyrimas, ji buvo dar ir nauja. Tačiau šio straipsnio rengimas gerokai užtruko, o per ši laikotarpi jau ir Lietuvoje pasirode keletas išsamių politologų darbų, kuriuose gana išsamiai aptariamos ne tik rinkejjų politinès preferencijos, jų rinkimini aktyvumą ir pan. lemiančios priežastys, bet analizuojama ir tiesiogiai su šio tyrimo tema susijusi rinkèjų elektorinès elgsenos problematika. Mums bene aktualiausi buvo politologo V. Morkevičiaus tyrimai, kurie 2017 m. pristatyti žurnale Politologija (T. 88. Nr. 4., str. Padalytas balsavimas 1996-2016 m. Seimo rinkimuose: mastas ir pobūdis) (Morkevičius, 2017), kuris vèliau (2018 m.) išplètotas kolektyvinèje monografijoje Ar galima prognozuoti Seimo rinkimus (str. Padalytas balsavimas Seimo rinkimuose: Lietuvos rinkejjas mégsta „dienos pietus" ar renkasi iš viso meniu?) (Morkevičius, 2018). Tačiau vis dažniau diskutuojant apie Lietuvos rinkimų sistemos optimizavimą, dèl demografinių priežasčių ịsismarkavusią daugumos rinkimų sistemai skirtų vienmandačių apygardų ribų kaitą, rinkejjų politinių preferencijų nestabilumą ir jų probleminị nuspẻjamumą (Jastramskis, 2018), šio tyrimo problematika išlieka aktuali. Be to, svarbiausiu tyrimo akcentu laikème padalyto balsavimo raišką teritoriniu požiūriu, detaliausiu - rinkimų apylinkių lygmeniu (3-oji publikacijos dalis), nes būtent smulkiausiu lygmeniu padalyto balsavimo raiška dar nebuvo analizuota. Tyrimo rezultatai gali būti ịdomūs ir politikams bei politinių partijų rinkimu kampanijų strategams. Vienmandatès kandidato ir ji delegavusios partijos sąrašo populiarumo sąveika daugiamandateje apygardoje politikams turètụ būti tikrai aktuali. Juk galima daryti prielaidą, kad vienmandatès kandidato populiarumas didina ir paties partijos sąrašo populiarumą toje konkrečioje teritorijoje. Tad šio tyrimo rezultatai galimai pasitarnautų politinèms partijoms parenkant tinkamiausius kandidatus vienmandatèse apygardose.

Tyrimo igyvendinimo galimybès. Tyrime naudojami 2012 m. ir naujausių - 2016 m. - Seimo rinkimu rezultatai. Visi tyrime naudojami duomenys yra viešai prieinami juos administruojančiame Vyriausiosios rinkimų komisijos (VRK) tinklalapyje (http://www.vrk.lt/) (Lietuvos Respublikos Vyriausioji..., 2018).

Temos tęstinumas. Periodiškai pasikartojantys ìvairaus tipo rinkimai - Seimo, Prezidento ir kt. - suteikia galimybę nuolatos atnaujinti duomenis, stebèti kintančius ir naujai atsirandančius dèsningumus, taip pat analizuoti rinkimų rezultatų teritorines priežastis. Šis tyrimas apima tik dvejų pastarųjų metų (2012 ir 2016 m.) Seimo rinkimus, tačiau vertinant šio darbo problematiką būtų galima ji plètoti ir chronologiškai, t. y. įtraukiant anksčiau vykusių ar būsimų rinkimų duomenis; metodologiškai - ittraukiant ìvairesnius tyrimo duomenis, pavyzdžiui, rinkëjų aktyvumo, sąrašų reitingavimo; įvairius sociodemografinius duomenis: gyventojų išsimokslinimo, amžiaus, tautybès statistinius rodiklius; suburbanizacijos proceso įtaką.

\section{TYRIMO TEORINIS IR METODOLOGINIS PAGRINDAS}

Kaip jau buvo minèta, asmenybinio ir partinio balsavimo atskyrimas, taip pat vienas iš jo padarinių - padalyto balsavimo reiškinys, po Lietuvos Respublikos nepriklausomybès atkūrimo buvo nulemti 1992 m. priimtu Lietuvos Respublikos Seimo rinkimų įstatymu ịtvirtintos mišrios paralelinès rinkimu sistemos (Lietuvos Respublikos Seimo..., 2019). Pirmaisiais atkurtos Lietuvos Respublikos gyvavimo metais reikejo nuspręsti, 
kokia rinkimu sistema gyvuos Lietuvoje. Tuo metu, Lietuvos partineje sistemoje dominuojant dviems pagrindinèms politinèms jègoms - ekskomunistinei Lietuvos demokratinei darbo partijai (LDDP) ir Sąjūdžiui, nuomonès išsiskyrè. Pirmoji - LDDP, taip pat kai kurios kitos atkurtos Nepriklausomos Lietuvos pirmaisiais gyvavimo metais veikusios politinès jègos, pavyzdžiui, Lietuvos liberalų sąjunga (LLS), pasisakè už proporcinę rinkimų sistemą, kadangi suprato, jog ju partinis palaikymas yra kur kas stipresnis nei asmenybinis, be to, tam ittakos turejo ir Skandinavijos šalių, taip pat mūsų kaimynių (Latvijos, Estijos, Lenkijos) pavyzdžiai. O Sąjūdžio parlamentinè dauguma palaikè iš sovietmečio paveldètą mažoritarinę rinkimų sistemą, kuri skatino rinktis valdžios atstovus kaip asmenybes. Galiausiai, siekiant sutarimo, buvo nuspręsta pasirinkti kompromisini variantą - Seimo rinkimuose itvirtinta mišri paralelinè rinkimų sistema, kuri ir veikia iki šiol.

Mišri paralelinė rinkimų sistema vienokia ar kitokia proporcija (Lietuvoje - iš esmès lygiomis dalimis) gana dirbtinai apjungia mažoritarinị (daugumos) ir proporcini rinkimų sistemos elementus. Priešingai nei taikant kitą mišrios sistemos atmainą - mišrią kompensacinę sistemą (ji taikoma, pvz., Vokietijoje, Vengrijoje), mišrios paralelinès sistemos atveju abu jos elementai tiesiogiai tarpusavyje (kompensavimo formulè) nèra susiję (Krupavičius, Pogorelis, 2004), tačiau netiesioginis ryšys per pasiūlos-paklausos santyki yra akivaizdus. Pirmiausia jis susijęs su kandidatų lūkesčiais ir rinkẻjų psichologija. Politologineje literatūroje tai vadinama „apkrètimo efektu" (angl. contamination effect) (Ferrara ir kt., 2005; Maeda, 2008; Jastramskis, 2018a; Morkevičius, 2018). Šis efektas pasireiškia tuo, kad jei vienmandateje apygardoje kandidatuoja rinkejjams gerai žinomas ir populiarus kurios nors partijos atstovas, tai jo dalyvavimas padidina ir tos partijos daugiamandatès apygardos sąrašo populiarumą toje vienmandateje apygardoje (Lietuvoje tai gana dažnas atvejis). Taip pat egzistuoja ir atvirkštinis ryšys - tuo metu valstybeje populiari politinè jèga gerokai padidina jai atstovaujančių net ir visuomenèje mažiau žinomų vienmandatès kandidatų populiarumą (LVŽS pavyzdys $2016 \mathrm{~m}$. Seimo rinkimuose). Tai itin aktualu nedaug žinomų politinių asmenybių turinčiose naujai susi- kūrusiose, tačiau populiariose partijose. Kartu ši priežastis prieštarauja bendro pobūdžio mažoritarinèms sistemoms būdingam dèsningumui, kad mažoritarine sistema ilgainiui formuoja dvipartinị formatą (kai nèra regioninių partijų) (Sartori, 2002). Mišriose paralelinèse sistemose šis dèsningumas gali ir neveikti (Lietuvos atvejis), nes "apkrètimo efektas" padeda politikoje išsilaikyti ne tik ittakingiausioms, bet ir mažiau ittakingoms politinems jègoms - yra ne be pagrindo tikimasi, kad ittakingesni kandidatai vienmandatese apygardose padidins ir partijos daugiamandates apygardos sąrašo populiarumą (Jastramskis, 2018a; Morkevičius, 2018).

Skiriamos kelios padalytą balsavimą mišriose paralelinèse rinkimų sistemose lemiančios priežastys (Plescia, 2016; Morkevičius, 2018):

1. Rinkejjai pasižymi skirtingais partiju ir kandidatu prioritetais. Lietuvoje tai bene dažniausiai pasitaikanti padalytą balsavimą lemianti priežastis, kuri kartu iliustruoja ir rinkèjų partinès tapatybès - tapatinimosi su kuria nors politine jèga, ištikimybès jai - lygị (Morkevičius, 2018). Ištikimiausius kandidatus turinčių partijų rinkèjai (pvz., Tėvynės sąungos - Lietuvos krikščionių demokratų (TS-LKD)) gerokai dažniau „nedalija" savo balso - balsuoja už tos pačios partijos sąrašą ir jos kandidatą vienmandatèje apygardoje (dažnai net jo asmeninès savybès bei žinomumas visuomeneje nebūna svarbūs). Tuo tarpu dažniau politines preferencijas keičiantys arba silpną partinę tapatybę turintys rinkẻjai daugiamandateje apygardoje balsuoja už vienos partijos sąrašą (su tam tikromis išlygomis - „ideologinis“ balsavimas), o vienmandatèse apygardose renkasi jiems labiausiai patinkantị kandidatą, iš esmès neatsižvelgdami ị jo partinę tapatybę.

2. Strateginis balsavimas. Nors mažoritarines rinkimų sistemas išlaikiusiose britiškos politinès tradicijos šalyse (JAV, JK ir kt.) yra gana dažnas - iš esmès jis ir sukuria dvipartinị formatą, tačiau Lietuvoje pasitaiko retai, nes strateginis balsavimas yra reiklus rinkejuc politinio išprusimo lygiui (Morkevičius, 2018). Strategiškai balsuojantis rinkejas sąmoningai siekia neiššvaistyti savo balso, todèl jei jam priimtinas vienmandatès apygardos kandidatas ar partijos sąrašas daugiamandateje apygardoje, jo manymu, neturi galimybių būti išrinktas (partijos sąrašas - peržengti minimalaus leidimo atstovauti barjero), tada jis 
renkasi labiausiai jam priimtiną realių galimybių būti išrinktam turintị kandidatą ar ịtakingesnę partiją, taip minimalizuodamas tikimybę, kad jo balsas bus „iššvaistytas“.

3. Priverstinis balso padalijimas. Tai daugiau „technine““ prielaida, kai rinkejui patinkanti partija dèl rinkiminio koalicinio susitarimo su jai artimomis partijomis, negebejimo iškelti kandidatu visose apygardose ir t. t. tiesiog toje vienmandatèje apygardoje neiškelia savo kandidato arba kandidatas dèl kokių nors priežasčiu atsisako toliau dalyvauti rinkimų kampanijoje. Rinkejjas tiesiog neturi galimybių vienmandateje apygardoje balsuoti už jam labiausiai priimtinos partijos kandidatą. Todèl „dalija“ savo balsą - daugiamandateje apygardoje balsuoja už jam patinkančios partijos sąrašą, o vienmandateje renkasi atstovaujantị kitai partijai ar nepartinị kandidatą. Tai itin aktualu regioninių bei teritoriškai neišvystytą organizacinę struktūrą turinčių partijų atvejais.

Kitos minètų autorių (Plescia, 2016; Morkevičius, 2018) išskirtos padalytą balsavimą lemiančios priežastys būdingos kompensacinèms mišrioms sistemoms, todèl čia nèra aptariamos.

Taigi, padalyto balsavimo raišką lemia paklausos ir pasiūlos veiksniai, o prielaidas jam atsirasti sukuria daugelio politologu kritikuojama mišri paralelinè rinkimų sistema. Tačiau mišrios paralelinès rinkimų sistemos kritikuojamos visai ne dèl padalyto balsavimo reiškinio, kuris pats savaime nèra joks negatyvus reiškinys ir politinio konsensuso tradicijos požiūriu gali būti vertintinas net teigiamai. Juk rinkẻjų pažiūrų lankstumas bei psichologinis ir emocinis nuosaikumas lemia ir jų remiamų politinių jègų panašią elgseną. Tai suformuoja pagrindą nuomonių pliuralizmui ir konsensuso tradicijai politikoje. Tačiau kartu, panašiai kaip ir taikant proporcinio atstovavimo rinkimų sistemą, padalytas balsavimas dažnai skatina ir partinès sistemos fragmentaciją, nes netgi ir mažiau įtakingos partijos, siekdamos išnaudoti „apkrètimo efektą“, net ir esant itin menkai tikimybei nugalèti, vienmandatèse apygardose kelia savo kandidatus, taip padidindamos tikimybę, kad jų remiamų kandidatų dalyvavimas padidins pačios partijos sąrašo galimybes daugiamandateje apygardoje. Pasitaiko atvejų (pvz., Lietuvos valstiečių ir žaliųjų sąjunga (LVŽS) ir jos pirmtakès iki $2016 \mathrm{~m}$. Seimo rinkimų; Lietuvos lenkų rinkimų akcija (LLRA) - iki 2008 m. Sei- mo rinkimų ir t. t.), kai mažoritarinis elementas mišriose paralelinèse sistemose ne mažina, o netgi didina šalies partinès sistemos fragmentaciją, nes tik mažoritarinès sistemos dèka neịtakingoms partijoms kartais pavyksta gauti vieną kitą mandatą.

Nèra vieningos nuomonès dèl padalyto balsavimo masto Lietuvoje. Politologai M. Jurkynas, analizuodamas $2008 \mathrm{~m}$. Seimo rinkimų duomenis, ir A. Ramonaité, remdamasi po $2012 \mathrm{~m}$. Seimo rinkimų vykdytos rinkejjų apklausos duomenimis, teigia, kad balso suskaidymas (padalytas balsavimas) Lietuvoje nèra labai didelis, ir šiuo aspektu Lietuvos rinkejai pasižymi balsavimo daugiamandatèje ir vienmandateje apygardose partiniu nuoseklumu (Jurkynas, 2009; Ramonaité, 2014). Po $2012 \mathrm{~m}$. Seimo rinkimų vykdytos apklausos duomenys rodo, kad nuo 70 \% (LRLS atveju) iki $90 \%$ (TS-LKD atveju) didžiųjų partiju rinkejjai teigè, kad vienmandateje ir daugiamandatèje balsavo už tą pačią politinę partiją bei jos atstovą (Ramonaité, 2014). Tuo tarpu V. Morkevičius, analizuodamas padalyto balsavimo reiškini detaliau, pastebi kiek kitokias padalyto balsavimo mastą labiau išryškinančias tendencijas (Morkevičius, 2018).

Padalytas balsavimas skirstomas $\mathfrak{i}$ „vertikalųji“ ir "horizontalujji“ (Plescia, 2016; Morkevičius, 2018). Vertikalusis - kai rinkejas skirtingo tipo rinkimuose balsuoja už skirtingas politines jègas. Šio tyrimo atveju jis nèra aktualus. O horizontalusis - tai šiame tyrime analizuojamas padalytas balsavimas, kai mišrioje rinkimų sistemoje rinkejjas daugiamandateje apygardoje balsuoja už vienos partijos sąrašą, o vienmandatejje - už kitos partijos ar nepriklausomą kandidatą.

Kadangi strateginis balsavimas tarp Lietuvos rinkejų nèra îsisavintas ir populiarus (Jastramskis, 2018b; Morkevičius, 2018), nemažai rinkëju balsų tiesiog „iššvaistoma“ - jiems nèra atstovaujama. Tai atskiro tyrimo reikalaujanti problema. Tačiau nebūtinai taip nutinka. Dalis rinkejuc iš tiesų sąmoningai pasirenka balsuoti už jiems gal ir mažiau priimtiną, tačiau realių galimybių nugalèti turintị kandidatą, arba minimalų leidimo atstovauti barjerą pajègią ìveikti partiją daugiamandateje apygardoje. Kartais toki pasirinkimą lemia ir techninès priežastys - kai rinkejjo remiama konkreti politine jèga dèl įvairių priežasčių nesukuria daugiamandatès apygardos sąrašo 
arba nekelia kandidatų vienmandatèje apygardoje (tinkamu kandidatu stoka; koaliciniai susitarimai ir pan.). Taip pat mégiamos partijos vienmandatès kandidatas rinkejjui tiesiog gali ir nepatikti. Visos šios prielaidos, kaip jau buvo minèta anksčiau, sukuria sąlygas padalyto balsavimo reiškiniui. Tačiau kaip rinkejjas renkasi priimtiniausią alternatyvą (kandidatą, partijos sąrašą)? Ar šiuo atveju veikia kokie nors dèsningumai, o gal viską lemia atsitiktinumai? Politologineje analizejje itin populiari klasikinè politiniu skirčiu (angl. political cleavages) teorija (arba tiksliau - keturiu kritiniu socialiniu takoskyru koncepcija) (Lipset, Rokkan, 1967) pakankamai aiškiai skiria universalias tradicines (tačiau vis dèlto labiau būdingas Vakarų visuomenèms) sociopolitines takoskyras (savininkas - darbininkas; bažnyčia - pasaulietinè valstybé; miestas - kaimas; centras - periferija). Neseniai dar socialistinès buvusios ir esmines santvarkos bei visuomenès transformacijas ką tik išgyvenusios Rytų ir Vidurio Europos šalys (ir Lietuva) turi kiek kitokią politinių konflikto linijų - takoskyrų formavimosi patirti (Ramonaitè, 2007). Kaip teigia A. Ramonaitè, Mechaniškai perkelti S. M. Lipset ir S. Rokkan modeli i visiškai kitoki istorini ir socialinị konteksta bütu ne tik klaidinga, bet ir prieštarautu esminei šių klasikų idejai - paaiškinti partiniu sistemu susiformavima atsekant istorine socialiniu ir kultüriniu takoskyru virtimo partinemis konflikto linijomis logikg (Ramonaitè, 2007, p. 10). Lietuvoje (kaip ir kitose postsocialistinèse Rytų ir Vidurio Europos šalyse) politinès konflikto ašys formavosi esant kitokiems istoriniams procesams - grubios priverstines sovietines modernizacijos ir 1988-1991 m. "dainuojančiosios revoliucijos" - metu, todel kaip tik čia galima rasti Lietuvos sociopolitines struktūros ir konkurencinés erdvès paaiškinima. Taigi, tik atsižvelgiant $i$ specifini Lietuvos posovietines visuomenès formavimosi konteksta, galima ieškoti autentišku politiniu skirčiu (Ramonaitè, 2007, p. 10). Vèlesni tyrimai, ypač po 2012 ir $2016 \mathrm{~m}$. Seimo rinkimų vykdyti nacionaliniai rinkejjų politinių nuostatų tyrimai, rodo, kad Lietuvoje svarbiausia visuomenę dalijanti takoskyra vis dar išlieka sovietmečio vertinimo (sovietinè - antisovietinè) skirtis (Ramonaitè, 2007, 2014, 2018), tačiau, keičiantis kartoms, jos reikšmè vis mažeja (Jurkynas, 2004; Ramonaitè, 2018) ir vis labiau dominuoja „besiblaškantis“ rinkèjas (Ramonaite,
2018). Lietuvoje taip pat gana aiškiai jaučiamos tautinè (pvz., lietuviai - lenkai, rusai) ir religinè (religingas - nereligingas) skirtys (Jastramskis, 2018b, 2018c; Ramonaite, 2018), tačiau jos turi arba gana aiškų regioninị aspektą (pvz., Rytų Lietuva), arba politiniams tikslams pasiekti išnaudojamos tik kai kurių politinių jègų (pvz., religinè skirtis - TS-LKD). Lietuvos rinkejuc pasirinkimui svarbus ir politinių jègų buvimo valdžioje vertinimas. Šiuo požiūriu mūsų rinkejjas reiklus ir gana nekantrus - iš išrinktos valdžios reikalauja greitų pokyčių (Jastramskis, 2018b). Tačiau ekonominiai ir kt. procesai yra lèti bei inertiški, todèl dažnas rinkejjas, nesulaukęs "greitų teigiamų pokyčių“, keičia savo politines simpatijas, rinkimuose pasirinkdamas vis kitas partijas. Didele dalimi tai ir paaiškina, kodèl Lietuvos partine sistema išlieka gana nestabili, o 2016 m. Seimo rinkimai parodè, kad iki brandžių demokratijų partinèms sistemoms būdingo didesnio stabilumo jai dar toli (nors ir Vakarų šalyse šiuo metu stebimas jų partinių sistemų stabilumo mažèjimas).

Tačiau kaip ir kitose demokratijose, taip ir Lietuvoje, partinè sistema iš esmès "paklūsta“ A. Dowinso erdvinès ideologinès konkurencijos teorijos (Dowins, 1957) désningumams - pagrindinès politinès jègos dažnai deklaruoja savo padètị partinès sistemos spektre (centro dešinè, centro kaire ir t. t.). Nors Lietuvoje nuoseklias ideologines nuostatas turinčių rinkejjų yra mažai (Ramonaitė, Jastramskis, 2014b), tačiau dažniausiai per apklausas dauguma jų sugeba save identifikuoti kairès-centro-dešinès politinio spektro skalèje (Jastramskis, 2018b). Panašu, kad tai nedaug ką bendro turi su erdvinès ideologinès konkurencijos teorijomis (dažnas rinkejjas ị tai nesigilina, be to, postsovietinèse šalyse kairès, centro ir dešinès samprata šiek tiek skiriasi nuo tradicinès jų sampratos), tačiau atspindi jų remiamos partijos deklaruojamą poziciją šalies kairès-centro-dešinès politinio spektro skaleje. Partijų saviidentifikacija vienoje ar kitoje politinio spektro dalyje kartu apibrèžia ir tam tikrus „ideologinius blokus“. Tai nèra vienintelè sąlyga politiniams partijų blokams atsirasti, tačiau grupuojantis partijoms jų pozicija politiniame spektre yra esminè. Pavyzdžiui, jau kuris laikas, maždaug nuo 2004 m. Seimo rinkimų iki 2016 m. Seimo rinkimų, šiek tiek stabilizavosi Lietuvos partinè struktūra, aiškų centro dešinès partijų politinị bloką sudarè TS-LKD ir 
Lietuvos Respublikos liberalų sąūdis (LRLS) (nuo 2006 m., iki tol - Lietuvos Liberalų ir centro sąjunga (LiCS)). Centro kairiajam blokui iš ittakingesnių partijų 2004-2016 m. priskirtinos Lietuvos socialdemokratu partija (LSDP), Darbo partija (DP), Partija „Tvarka ir teisingumas“ (PTT), taip pat regioniné partija - Lietuvos lenkų rinkimų akcija (LLRA). Nuo 2016 m. centro kairiajam blokui galima priskirti ir $2016 \mathrm{~m}$. rinkimuose gerokai išpopuliarejjusią politinę jègą - LVŽS. Tačiau toks skirstymas gana paviršutiniškas, nes, pavyzdžiui, LSDP skiriasi nuo protesto partijų (DP, PTT ir kt.) formuodama „sisteminès“ partijos ịvaizdị. Tokị, kad ir su tam tikromis išlygomis, pavyzdžiui, LVŽS, PTT turi ir dešiniųjų partijų bruožų, politinių jègų grupavimąsi patvirtina ir Lietuvos partinès sistemos tyrimai (Ramonaité, Jastramskis, 2014a; Jastramskis, 2018b). Galima teigti, kad iš esmès Lietuvoje susiformavo du aiškesni įtakingų partijų blokai - centro dešinès (TS-LKD, LRLS, LiCS) ir centro kairès (LSDP, DP, PTT, LLRA, LVŽS). Toks politinis spektras turi įtakos ir padalytam balsavimui (Morkevičius, 2018) bei rinkejų politinėms preferencijoms antrajame rinkimų ture - pastebèta, kad rinkejjai jau negaledami rinktis iškritusio jiems labiausiai priimtino kandidato, dažniau balsuoja už to paties bloko partijų kandidatus (tai aiškiai patvirtino LVŽS kandidatų sẻkmé 2016 m. Seimo rinkimų antrajame ture), taip pat rinkejams patrauklesnès yra labiau centristines, nuosaikesnes pozicijas užimančios politinès partijos ir jų remiami kandidatai (Jastramskis, 2018b). Taigi, padalyto balsavimo atvejais rinkejai dažniausiai renkasi to paties politinio bloko partijas ir kandidatus (tiesa, rinkejų apklausos ne visada tai patvirtina) (Morkevičius, 2018).

$2012 \mathrm{~m}$. Seimo rinkimams skirtoje kolektyvinejje monografijoje Kaip renkasi Lietuvos rinkejjai? Idejos, interesai ir ịvaizdžiai politikoje publikuotame A. Ramonaitès straipsnyje Kaip žmonés renkasi už kq balsuoti? Pasirinkimo logika ir partine tapatybe (Ramonaite, 2014) analizuojama, kaip gyventojai renkasi už ką balsuoti - kiek šis pasirinkimas kinta, kiek jis stabilus, ar rinkejams svarbi partija, ar tik kandidatuojančios personalijos. Publikacijos autoré gilinasi $\mathfrak{i}$ partinés tapatybès raišką Lietuvoje, mėgindama suprasti, ar santykinai naujoje demokratijoje rinkejjai apskritai gali būti prisirišę prie kokios nors partijos ir, jeigu taip, kokios yra pagrindinès šio prisirišimo prielaidos. Publikacijoje pateikti sociologinio tyrimo rezultatai rodo, kad vis dèlto dauguma Lietuvos rinkejuc prioritetą teikia partiniam balsavimui (kas šiek tiek paneigia vyraujantị požiūrị, kad Lietuvos rinkejams priimtinesnis asmenybinis balsavimas). Pagal atiduodamas simpatijas vienai ar kitai partijai (analizuojama 13 ịtakingiausių politinių jègų) rinkejjai buvo suskirstyti i kelis tipus (Ramonaitè, 2014):

1. Rinkejjai, kurie visada balsuoja už vieną ar tą pačią partiją, pavyzdžiui, TS-LKD ar LSDP. Toks rinkejų pasirinkimas, anot tyrimo autorių, yra paaiškinimas rinkejuc emociniu prisirišimu.

2. Rinkejjai, kurie neturi savo lyderès (politinès jègos), tačiau jų pasirinkimas apsiriboja tuo pačiu politiniu bloku, t. y. „dešiniųjų " pažiūrų rinkejjai balsą atiduoda už TS-LKD arba liberalų (LRLS, LiCS) partijas, o „kairiujų“ - už LSDP, DP arba PTT.

3. Rinkèjai, neturintys aiškių politinių pažiūrų, t. y. jų balsas rinkimuose atiduodamos toms partijoms, kurias remia jų artimiausia aplinka (artimieji, pažįstami ir t. t.), arba vadovaujamasi vyraujančiomis nuotaikomis visuomenèje (balsuoja už ịvairias "gelbètojų“ partijas ir pan.).

2016 m. Seimo rinkimų rezultatai šiek tiek koregavo ankstesnių rinkimų rezultatų ir porinkiminių gyventojų apklausų analizès išvadas (pvz., LSDP elektoratas nèra taip tvirtai prisirišęs prie šios partijos, kaip manyta anksčiau), tačiau 2014 m. A. Ramonaitès parengtoje publikacijoje išskirti trys rinkejų tipai yra pakankamai universalūs - jie išliko ir $2016 \mathrm{~m}$. Seimo rinkimuose.

Šiek tiek nutolstant nuo mišrioms sistemoms būdingo padalyto balsavimo reiškinio, gyventoju rinkiminès elgsenos teritoriniai ypatumai (prezidento rinkimuose) buvo analizuojami W. G. Jacoby veikale Ideologija ir balso atidavimas $2004 \mathrm{~m}$. rinkimuose (Jacoby, 2009). Tyrimas apėmė rinkejų politinių preferencijų dviems didžiausioms JAV partijoms - Respublikonų ir Demokratu bei tuometinių šių partijų lyderių - Dž. V. Bušo (RP) ir Dž. Kerio (DP) populiarumo analizę. Buvo vertinamas rinkejjų politinių preferencijų šioms partijoms ir jų lyderiams priežastingumas partiniu-ideologiniu bei Dž. V. Bušo ir Dž. Kerio asmenybès bruožų aspektais. Atlikus tyrimą paaiškèjo, kad didžiausią vaidmenị $2004 \mathrm{~m}$. JAV prezidento rinkimuose, kuriuose varžèsi abu šių partijų lyderiai, atliko partinès preižastys. Rinkejjai 
pirmiausia balsavo už partiją, kuriai labiau simpatizuoja, o kandidato asmeninès savybès, nors ir buvo labai svarbios, tačiau apsisprendžiant rinkejjams buvo antraeilès (Jacoby, 2009).

JAV mokslininkai J. M. Carey ir M. S. Shugartas nagrinejo asmenybinio ir partinio balsavimo santykį. Darbe autoriai teigia, kad kandidatu asmeninè reputacija ir asmenybès bruožai yra kur kas svarbesni nei kuriai partijai jie atstovauja. Šiame tyrime pateikiami ịvairių šalių (Izraelio, Ispanijos, Šveicarijos, Lenkijos, Maltos, Brazilijos, Japonijos ir kt.) rinkimų rezultatai ir bandoma išsiaiškinti, kaip rinkejai balsavo, t. y. atsižvelgia t politiko savybes ir pačią asmenybę ar vis dèlto labiau palaiko tam tikrą politinès partijos sąrašą (Carey, Shugart, 1995).

Kitų autorių darbuose rinkëjų politinių preferenciju prielaidos buvo nagrinejamos ir centro-periferijos aspektu. J. E. Oliveris ir S. E. Ha, remdamiesi rinkimų rezultatais ir rinkejų apklausa, nagrinèjo asmenybinị balsavimą (Oliver, Ha, 2007). Tyrimo rezultatai parode, kad periferijoje santykinai didesnę ittaką turi asmenybinis balsavimas: labiau palaikomas tas kandidatas, kuri asmeniškai pažįsta rinkejjai, o miestuose asmenybinis balsavimas pasireiškia gerokai rečiau. Miesto rinkejjai labiau linkę vadovautis ideologinemis nuostatomis - šiuo atveju svarbiausias veiksnys yra kandidato politinès pažiūros ir partija, kuriai jis atstovauja (Oliver, Ha, 2007). Panašus dèsningumas būdingas ir Lietuvai. Kaip ir Vakarų šalyse, taip ir Lietuvoje, didmiesčiai laikomi vienu iš patogiausių elektorinio geografinio tyrimo objektų, nes mažesnis (nei provincijoje) „asmenybinio balsavimo" poveikis leidžia atlikti objektyvesni tyrimą, rinkejjų politines preferencijas grindžiant pirmiausia socialiniais, kultūriniais ir kt. veiksniais (Baranauskaite, Tučas, 2014).

Siekiant geriau suprasti Lietuvos rinkejų asmenybines ir partines politines preferencijas centras-periferija pjūviu, visos Lietuvos rinkimų apylinkès buvo sugrupuotos i šešias kategorijas, kurios skaleje centras-periferija išsidèto taip: 1) didžiųjų miestų apylinkès (Vilnius, Kaunas, Klaipèda, Šiauliai, Panevėžys ir Alytus); 2) priemiesčių apylinkès; 3) vidutinių miestų apylinkès (per 5 tūkst. gyv.; $\mathfrak{i}$ šią grupę ịtraukti ir šiek tiek mažesni savivaldybių centrai); 4) mažų miestų (iki 5 tūkst. gyv.) apylinkès; 5) miestelių ir didesnių gyvenviečių apylinkès (turi mokyklas, kt. ịs- taigas); 6) kaimiškos apylinkès. Dèl ribotos publikacijos apimties detalesnis apylinkių skirstymas i šias kategorijas bei kiti smulkesni tyrimo metodologininiai niuansai šiame straipsnyje neaptariami. Detalesni tyrimo rezultatai, taip pat su šia tema glaudžiai susijusi kandidato vietos partijos sąraše pokyčio teritorine analizè, išsamiau pateikti A. Vikšraitienès magistro darbe Asmenybinio ir partinio balsavimo teritorine diferenciacija Lietuvoje (Vikšraitienè, 2018).

\section{PARTIJŲ IR KANDIDATŲ POPULIARUMO KAITOS REGIONINIAI ASPEKTAI}

Tyrimo rezultatai rodo, kad Seimo rinkimų vienmandatèse apygardose padalyto balsavimo atvejų, vertinant tik pirmųjų turų rezultatus, $2016 \mathrm{~m}$. Seimo rinkimuose buvo gerokai daugiau nei 2012 m. (žr. 1 lentelę). 2012 m. Seimo rinkimu pirmajame ture iš 71 vienmandatès apygardos 21 fiksuotas padalyto balsavimo atvejis (tekste dar bus vadinama "nugaletojai nesutampa"). Tuo tarpu 2016 m. Seimo rinkimu pirmajame ture - jau 28 padalyto balsavimo atvejai.

Kadangi rinkimų apygardos, skirtingai nei apylinkès, rinkëjų skaičiumi yra panašaus dydžio, apygardų teritorinis lygmuo yra tinkamas nustatyti padalyto balsavimo santykinị svorị skirtingu politinių jègų atžvilgiu (žr. 1 lentelę).

Iš Lietuvos įtakingiausių partijų rinkèjų politinių preferencijų stabilumu pirmiausia išsiskyre TS-LKD. Gausybè Lietuvos rinkejjų politinių preferencijų tyrimų rodo, kad patị lojaliausią elektoratą turi dvi Lietuvos politinès partijos - TS-LKD ir LLRA (Jastramskis, 2018b, 2018c; Morkevičius, 2018; Ramonaite, 2007, 2014, 2018; ir kt.). Tiriamuoju 2012-2016 m. laikotarpiu (kaip ir iki tol) TS-LKD išsiskyrè gana dideliu ir stabiliu rinkejų politinių preferencijų šiai partijai atvejų skaičiumi - net 16-oje vienmandačių apygardų 2012 ir $2016 \mathrm{~m}$. pirmavo šios partijos daugiamandates apygardos sąrašas bei jos remiamas vienmandatès apygardos kandidatas. Jau seniai tai būdinga iš esmès visoms Kauno, daugumai Vilniaus Seimo rinkimų vienmandačių apygardų. Tai itin ryšku buvo ir 2012 m., tačiau 2016 m. situacija Kaune ženkliai pasikeitè - Šilainių (Nr. 14) rinkimų apygardoje pirmajame rinkimų ture pirmavo LVŽS sąrašas ir šios partijos lyderis R. Karbauskis, kai kuriose kitose apygardose (Kalniečių (Nr. 15), 
1 lentelè. Padalytas balsavimas pagal politines jègas 2012 ir $2016 \mathrm{~m}$. Seimo rinkimuose. 1 - vienmandatẻje apygardoje pirmaujant partijos sąrašui, joje pirmajame rinkimų ture nugalëjo tos pačios partijos remiamas kandidatas („nugalètojai sutampa“); 2 - kandidatui pirmajame rinkimų ture nugalëjus vienmandatẻje apygardoje, jos teritorijoje pirmavo kitos partijos sąrašas (padalytas balsavimas); 3 - vienmandatèje apygardoje pirmaujant partijos sąrašui, joje pirmajame rinkimų ture nugalèjo kitos partijos remiamas arba nepriklausomas kandidatas (padalytas balsavimas)

Table 1. Split-ticket voting according to political allegiance in 2012 and 2016 Seimas election. 1 - Party-list wins in Single-member Constituency and the candidate supported by the same party wins in the 1st election round ("winners match"); 2 - Candidate wins in the 1st election round in Single-member Constituency, winning partylist is that of a different party (split-ticket voting); 3 - Party-list wins in Single-member Constituency, the winning candidate in the 1st election round is independent or supported by a different party (split-ticket voting)

\begin{tabular}{c|c|c|c|c|c|c}
\hline \multirow{2}{*}{$\begin{array}{c}\text { Partija } \\
\text { Party }\end{array}$} & \multicolumn{3}{|c|}{$\mathbf{2 0 1 2} \mathbf{~ m .}$} & \multicolumn{3}{c}{$\mathbf{2 0 1 6} \mathbf{~ m .}$} \\
\cline { 2 - 8 } & $\mathbf{1}$ & $\mathbf{2}$ & $\mathbf{3}$ & $\mathbf{1}$ & $\mathbf{2}$ & $\mathbf{3}$ \\
\hline TS-LKD & 16 & 7 & 1 & 16 & 6 & 9 \\
\hline LRLS & 1 & 3 & 1 & 0 & 4 & 0 \\
\hline LSDP & 13 & 6 & 4 & 4 & 6 & 0 \\
\hline DP & 13 & 0 & 13 & 1 & 2 & 0 \\
\hline LVŽS & 0 & 1 & 0 & 17 & 4 & 18 \\
\hline PTT & 3 & 2 & 0 & 2 & 2 & 0 \\
\hline LLRA & 4 & 0 & 1 & 3 & 0 & 1 \\
\hline DK & 0 & 0 & 1 & 0 & 0 & 0 \\
\hline $\begin{array}{c}\text { Nepriklausomi ir mažujų partiju kandidatai } \\
\text { Independent and minor party candidates }\end{array}$ & - & 2 & - & - & 4 & - \\
\hline Iš viso / Total & 50 & 21 & 43 & \multicolumn{2}{c}{28} \\
\hline
\end{tabular}

Aleksoto-Vilijampolès (Nr. 19)), pirmaujant TSLKD daugiamandatès apygardos sąrašui, pirmajame rinkimų ture nugalëjo LVŽS kandidatai (žr. 2 pav.). Taigi, iš esmès „pavyzdineje TS-LKD tvirtovèje“ - Kaune 2016 m. Seimo rinkimuose šios partijos pozicijos gerokai „sušlubavo“. Tiesa, pirmajame rinkimų ture padalyto balsavimo atvejų Kaune nebuvo tiek daug (tik 2), tačiau antrajame rinkimų ture beveik visose Kauno rinkimų apygardose, išskyrus Centro-Žaliakalnio (Nr. 13), TS-LKD kandidatus ìveikè LVŽS remiami politikai. Vilniuje situacija keitèsi nedaug. Nors Vilniuje ir ankstesniuose Seimo rinkimuose populiariausia išlikdavo TS-LKD, tačiau šios partijos įtaka jau nebuvo tokio ryški, ir visada sostineje pasitaikydavo padalyto balsavimo atvejų (pvz., 2012 m. - 1; 2016 m. - 3). Tiesiog Vilnius ir jo metropolinis regionas rinkèjų politinių preferencijų požiūriu yra gerokai „margesnis“, taip pat ir teritoriniu aspektu (Savickaite ir kt., 2013; Baranauskaitè ir kt., 2015). Sumenkusią TS-LKD įtaką Kaune iš dalies kompensavo išaugęs šios partijos populiarumas Klaipedoje. Tikètina, kad dalis LRLS nusivylusių rinkejjų $2016 \mathrm{~m}$. Seimo rinkimuose parèmé TS-LKD sąrašą ir jai atstovaujamus politikus vienmandatèse apygardose. Provincijos vienmandatėse rinkimų apygardose, kuriose tradiciškai gana populiari TS-LKD, dažniausiai fiksuojamas padalytas balsavimas - $2012 \mathrm{~m}$. Seimo rinkimuose geriau sekèsi TS-LKD vienmandačių kandidatams (padalyto balsavimo atvejais 7 nugalejo šios partijos remiami kandidatai, ir tik 1 - pirmavo TS-LKD sąrašas), o $2016 \mathrm{~m}$. Seimo rinkimuose padalyto balsavimo atvejais jau dominavo TS-LKD sąrašas ( 9 iš 15 atvejų). Tiesa, tai buvo būdinga ne tik provincijos, bei ir kai kurioms Kauno, Klaipedos ir Vilniaus apygardoms. Provincijoje 2016 m. nuosekliai už TS-LKD sąrašą ir kandidatą balsavo tik Garliavos (Nr. 66) ir Dzūkijos (Nr. 69) apygardų rinkejjai (2012 m. tokiu atvejų provincijos apygardose iš viso nebuvo). Taigi, nors nemažoje dalyje provincijos vienmandačių rinkimų apygardų TS-LKD kandidatai yra gana populiarūs, tačiau rinkejjai nèra pakankamai nuoseklūs - dažniausiai balsuoja už kitos partijos (2012 m. - DP, LSDP, LRLS; 2016 m. - LVŽS) sąrašą. Kauno, o ypač Vilniaus, rinkëjų politinès preferencijos tiriamuoju laikotarpiu buvo gerokai stabilesnès - ir istoriniu aspektu, ir gerokai mažesniu padalyto balsavimo atvejų skaičiumi. 


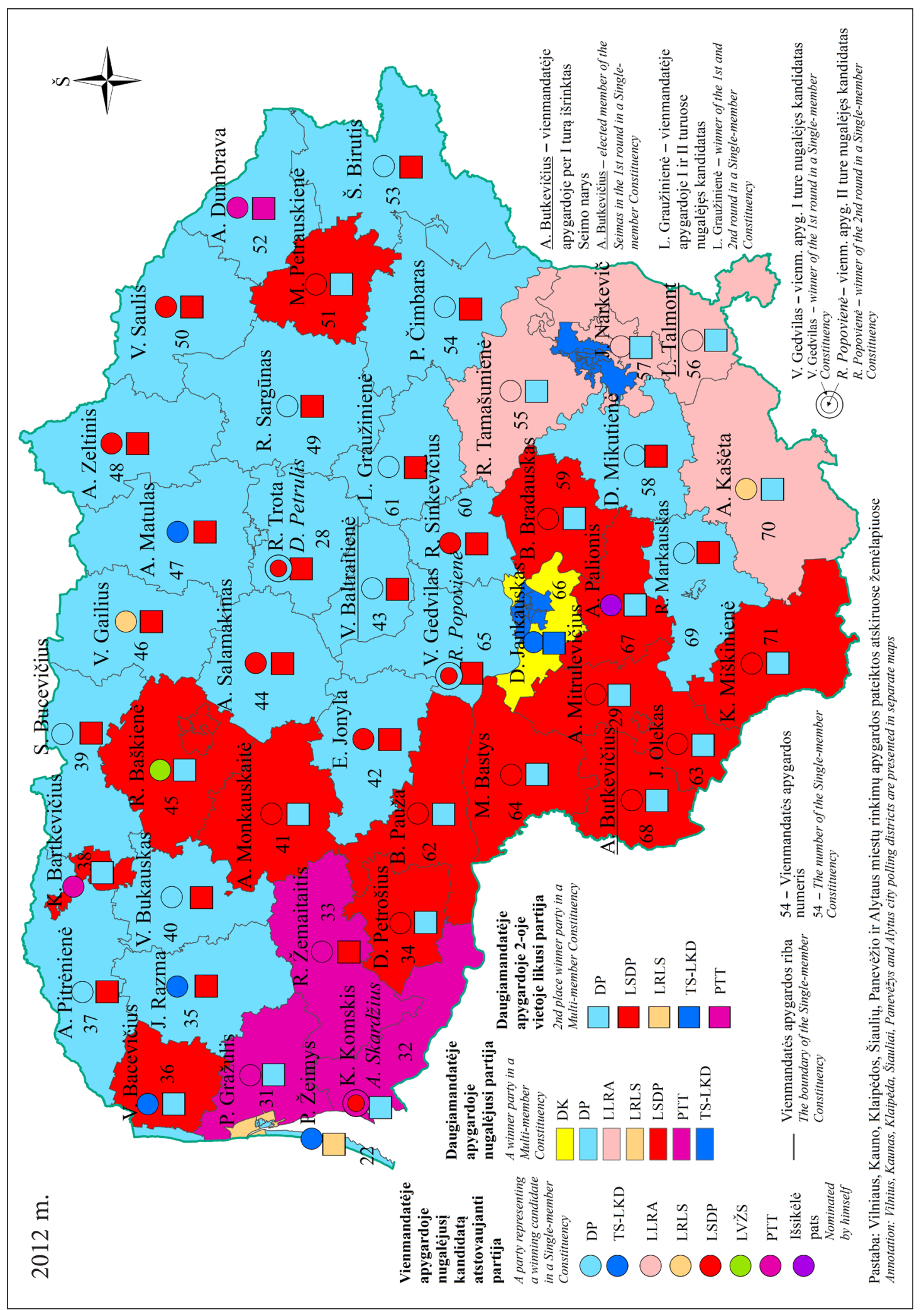



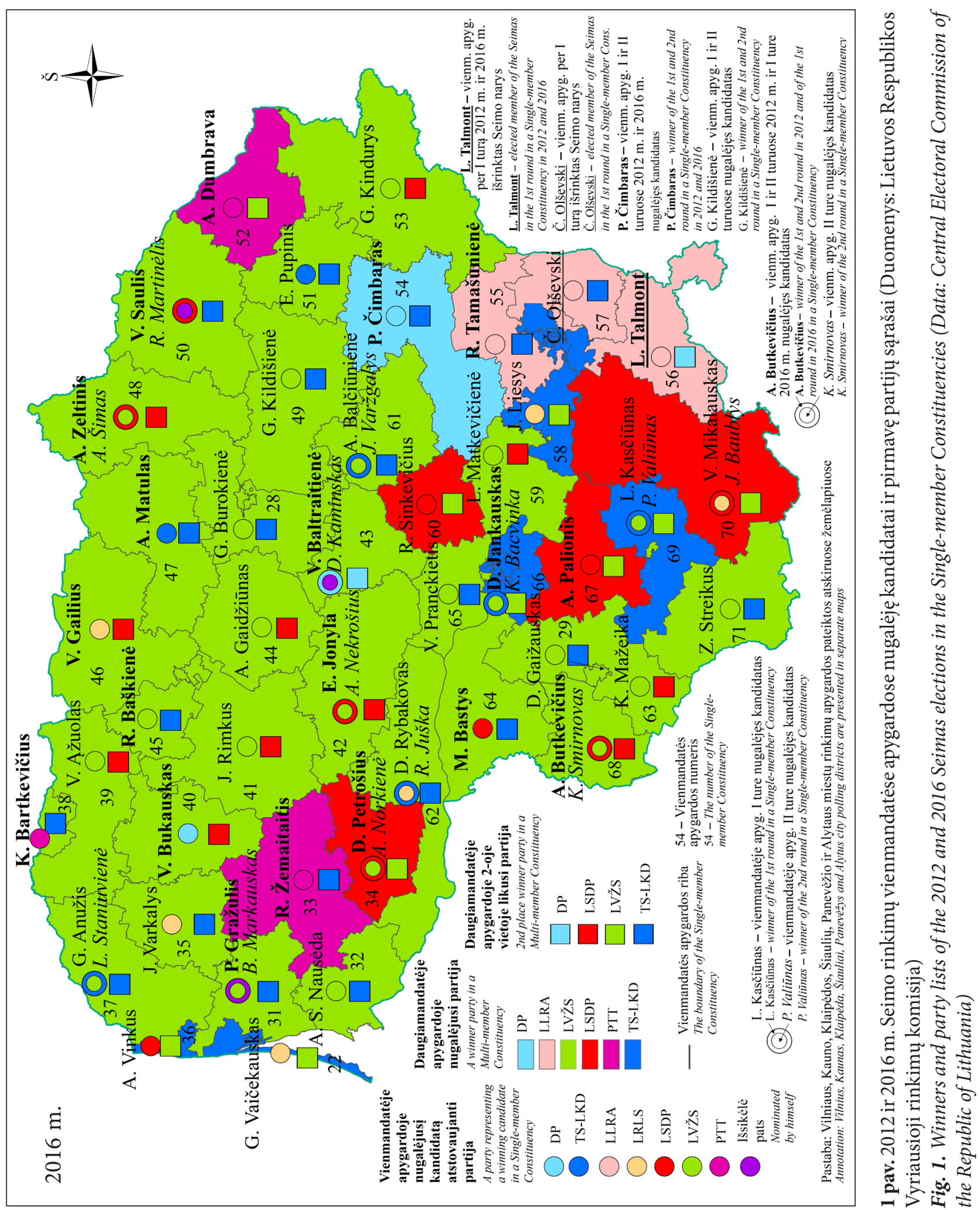
Regioninè partija - LLRA, nors yra labai populiari tik Pietryčių Lietuvoje, tačiau išsiskiria itin stipriu regiono rinkejjų politinių preferencijų šiai partijai istoriniu nuoseklumu ir stabilumu. 2012 m. Seimo rinkimuose šios partijos remiami kandidatai ir jos sąrašas pirmavo 4, 2016 m. - 3 vienmandatèse rinkimų apygardose. Mažesni skaičių $2016 \mathrm{~m}$. lèmè ne rinkèjų politinių preferencijų kaita, o prieš 2016 m. atlikta Seimo rinkimų vienmandačių apygardų ribų reforma, nors ì Vilniaus suburbanizacijos zoną patenkančiose rinkimų apylinkèse (ypač Nemenčinès (Nr. 55) apygardoje) jaučiama ir gyventojų sudèties kaitos itaka (Savickaite ir kt., 2013). Tik Naujosios Vilnios (Nr. 10) rinkimų apygardoje rinkejjų politinès preferencijos LLRA nèra itin nuoseklios - 2012 ir 2016 m. rinkimuose apygardos ribose pirmajant LLRA sąrašui, joje pirmajame ture nugalejo kitų partijų remiami kandidatai.

Visų kitų partijų rinkèjų politinès preferencijos buvo mažiau nuoseklios (santykinai daugiau padalyto balsavimo atvejų) ir labai kaičios (lyginant 2012 ir 2016 m. Seimo rinkimus). Net LSDP, kuri anksčiau turèjo santykinai gana nemažai lojalių rinkejų (Ramonaitè, 2014), 2016 m. Seimo rinkimuose ittaką prarado net dalyje tų vienmandačių apygardų (vietą užleisdama LVŽS), kuriose tradiciškai jau kuris laikas ji buvo populiariausia: Vilkaviškio (Nr. 68), Kelmès (Nr. 41), Kaišiadorių-Elektrènų (Nr. 59), Sūduvos (Nr. 63), abiejose Šiaulių m. rinkimų apygardose. Dominuojančią ittaką LSDP sąrašas išlaikè tik Prienų-Birštono (Nr. 67) ir Tauragès (Nr. 34) rinkimų apygardose. Jei 2012 m. Seimo rinkimuose sutampančio balsavimo atvejų vienmandatèse apygardose skaičiumi (13) LSDP mažai tenusileido TS-LKD (žr. 1 lentelę), tai 2016 m. situacija (priešingai nei TS-LKD atveju) gerokai pasikeitè - rinkèjų politinių preferencijų LSDP nuoseklumu išsiskyrè tik minètos Prienu-Birštono (Nr. 67), Tauragès (Nr. 34), Jonavos (Nr. 60) ir Varénos-Traku (Nr. 70) vienmandatès rinkimų apygardos. Tačiau padalyto balsavimo atvejų skaičius taip pat sumažejo (2012 m. 10 atvejų; 2016 m. 6 atvejai (ir visi, nugalejus LSDP vienmandatès apygardos kandidatui)), nes $2016 \mathrm{~m}$. Seimo rinkimuose LSDP populiarumas ženkliai sumenko. Panašu, kad bent dali jos šalininkų perviliojo LVŽS.

Partija „Tvarka ir teisingumas" (PTT) tiriamuoju laikotarpiu iš dalies sugebejo išlaikyti savo ittaką pietineje Žemaitijos dalyje ir ji padidinti nuo šio regiono gerokai nutolusioje daugiatautèje Visagino-Zarasų (Nr. 52) rinkimų apygardoje. Taigi, bent jau šiuose dviejuose Lietuvos regionuose galima kalbèti apie rinkẻjų politinių preferencijų PTT stabilumą. $2012 \mathrm{~m}$. net trijų gretimų pietinès Žemaitijos dalies vienmandačių rinkimų apygardų - Gargždų (Nr. 31), Šilutès-Pagègių (Nr. 32) ir Šilalès-Šilutès (Nr. 33) - rinkejjai iš visos Lietuvos konteksto išsiskyrè politinių preferencijų PTT nuoseklumu - pirmajame rinkimu ture aktyviausiai balsavo už PTT sąrašą bei jos remiamus vienmandačių apygardų kandidatus. Čia buvo susiformavęs gana aiškus didesnès paramos PTT elektorinis regionas. Tačiau 2016 m. šiame regione nuosekliomis rinkejjų politinėmis preferencijomis išsiskyre tik naujai sudaryta Pietų Žemaitijos (Nr. 33) vienmandatė rinkimų apygarda. Tiesa, kaip jau buvo minèta, Šiaurès Rytu Lietuvoje tokia tapo ir Visagino-Zarasų (Nr. 52) rinkimų apygarda. Gargždų (Nr. 31) ir Mažeikių (Nr. 38) vienmandatèse rinkimų apygardose pirmajame rinkimų ture nugalejo tik šios partijos remiami kandidatai.

Sparčiai augusi populiarumą ir aiškų dominavimą Klaipeddos mieste prarado Lietuvos Respublikos liberalų sąjūdis (LRLS). Gana neblogi šios partijos rezultatai $2016 \mathrm{~m}$. Seimo rinkimuose buvo nulemti bendro partijos ir jos kandidatų populiarumo Lietuvos didžiuosiuose miestuose bei kai kuriose provincijos vienmandatèse rinkimu apygardose. Tuo tarpu tam tikras ryškesnis LRLS populiarumas Klaipèdos, Vilniaus ir kt. Lietuvos miestuose gerokai sumenko. Paprastai LRLS daugiamandatès apygardos sąrašui būdinga santykinai nemaža rinkejjų parama Lietuvos didmiesčiuose (juose dažniausiai užima antrą-ketvirtą vietas), tačiau aiškesnių regionų, kuriuose vyrautų nuosekliai už šios partijos sąrašą ir vienmandačių kandidatus balsuojantys rèmėjai, tiesiog nèra. Ilgą laiką išimtị sudare Klaipėdos miestas, kurio dalyje apygardų pirmaudavo LRLS sąrašas. Pavyzdžiui, $2012 \mathrm{~m}$. Seimo rinkimuose tokios apygardos Lietuvoje buvo dvi ir abi Klaipèdos mieste. Iš jų Marių (Nr. 21) rinkimų apygardoje rinkejjai balsavo ir už šios partijos remiamą kandidatą. Santykinai ryškesnès Klaipėdos miesto gyventojų politinès preferencijos liberalams aiškinamos ịvairiai. Pirmiausia Klaipèda, kaip jūrų uostas, tradiciškai yra gana liberali, miestas gyventojų socialine ir 


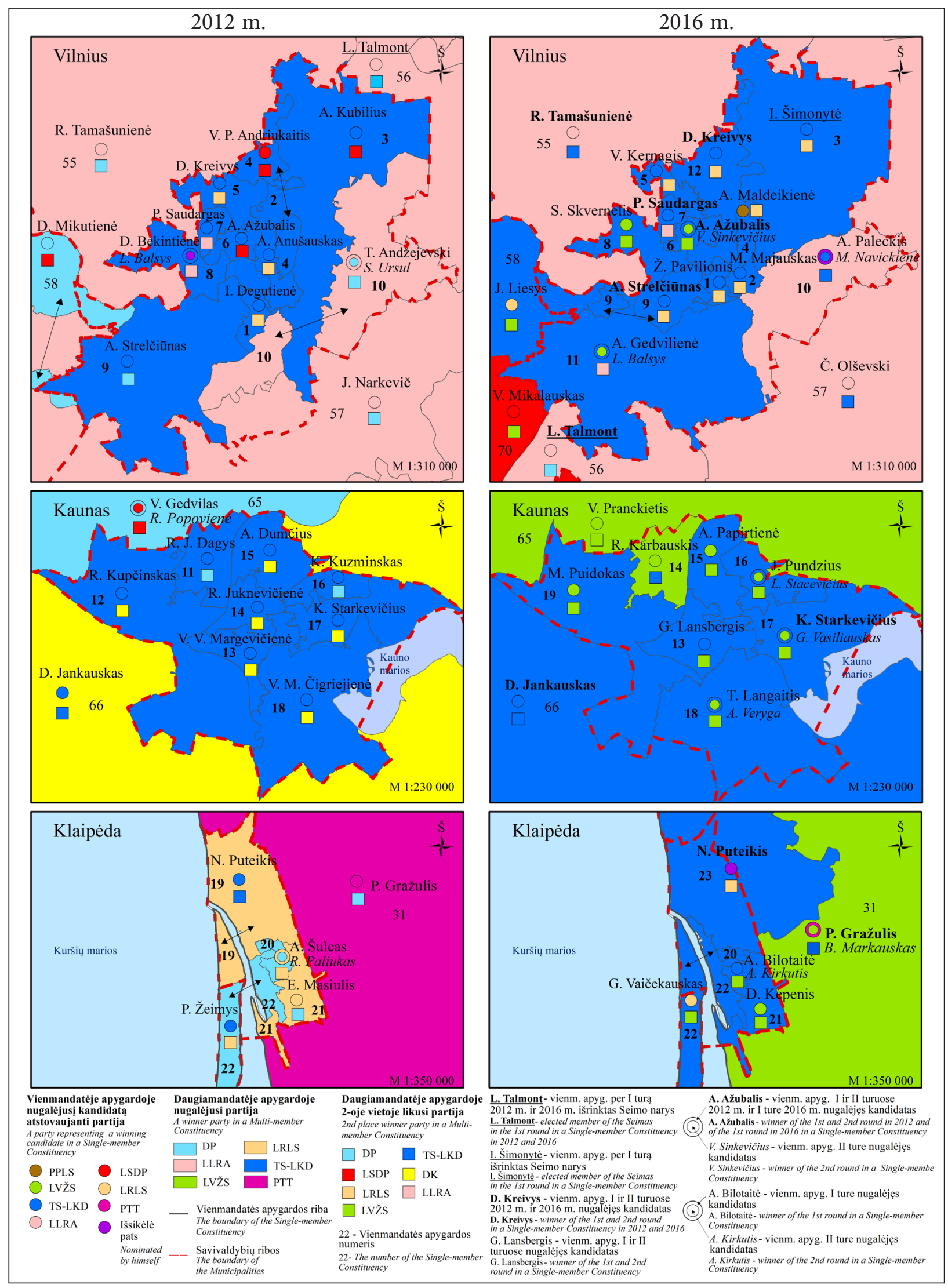

2 pav. 2012 ir 2016 m. Seimo rinkimų (Vilniaus, Kauno ir Klaipėdos miestų) vienmandatèse apygardose nugalëję kandidatai ir pirmavę partijų sąrašai (Duomenys: Lietuvos Respublikos Vyriausioji rinkimų komisija)

Fig. 2. Winners and party lists of the 2012 and 2016 Seimas elections in the Single-member Constituencies (Vilnius, Kaunas and Klaipeda cities) (Data: Central Electoral Commission of the Republic of Lithuania) 
etnine sudètimi primena Vilnių (Klaipèdos gyventojų sudetis dar labiau nei Vilniaus pasikeite sovietmečiu), tačiau sociologiniai tyrimai rodo (Baranauskaitè ir kt., 2015), kad Klaipėdoje, skirtingai nei Vilniuje, etninis veiksnys neturi nors kiek didesnès įtakos socialinei atskirčiai atsirasti. Netgi priešingai - dažnai tarp aukštesnes pajamas gaunančių asmenų vyrauja etninių mažumų atstovai. Tad galima daryti prielaidą, kad Klaipèdoje didesnes pajamas gaunančiam centro dešiniųjų pažiūrų rinkejjui priimtinesnis LRLS, nei konservatyvesnes politines nuostatas deklaruojanti TS-LKD. Kad šios liberalios partijos sąrašas nugalètų apygardoje, nepakanka vien tik didesnes pajamas gaunančių, išsilavinusių jaunesnio amžiaus rinkejjų (taip dažniausiai apibūdinamas liberalių pažiūrų rinkejjas) balsų. Tačiau esant aiškiam LRLS dominavimui aukštesnio socialinio statuso gyventojų sluoksniuose tokios politinès nuostatos per socialinius tinklus perduodamos ir žemesnių socialinių sluoksnių gyventojams. Aišku, tai tik prielaidos, tačiau jos pakankamai logiškai paaiškina santykinai gana dideli LRLS populiarumą Klaipėdoje. Tiesa, nežiūrint visko, 2016 m. situacija Klaipédoje gerokai pasikeitè. Nors LRLS sąrašas ir jo remiami kandidatai Klaipédoje liko gana populiarūs, tačiau juos aplenkè TS-LKD (partijos sąrašas pirmavo visose Klaipèdos vienmandatèse rinkimų apygardose), o LRLS populiarumas ženkliai smuko. Neabejotinai tam itakos turejo $2016 \mathrm{~m}$. teisésaugos pateikti ịtarimai LRLS. Tačiau kai kuriose regiono nesudarančiose kaimiškose rinkimų apygardose (Plungès (Nr. 35), Žiemgalos (Nr. 46), Trakų-Vievio (Nr. 58)), taip pat dalị Klaipédos m. ir Neringą jungiančioje Pajūrio (Nr. 22)) populiariausi išliko LRLS kandidatai.

DP ir LVŽS populiarumo kaitą geografiniu požiūriu bei padalyto balsavimo su šiomis partijomis susijusių atvejų dažni prasminga aptarti kartu. Pirmiausia, palyginus 2012 ir 2016 m. Seimo rinkimų proporcinès dalies rezultatus regioniniu požiūriu, akivaizdu, kad LVŽS 2016 m. daugiamandatès apygardos sąrašas labai dažnai pirmavo tose vienmandatèse rinkimų apygardose, kuriose 2012 m. pirmavo DP sąrašas. Aišku, ne tik ten. Jau buvo užsiminta, kad LVŽS dalị vienmandačių apygardų „perème““ ir iš kai kurių kitų partijų (pirmiausia - LSDP), tačiau LVŽS geriausiai sekèsi tose apygardose, kuriose iki tol populiariau- sia buvo DP. Panašumų tarp šių dviejų partijų rinkejuc elgsenos yra ir daugiau - abiem atvejais gana nemažą padalyto balsavimo atvejų skaičių (DP 2012 m. - 13 atvejų; LVŽS 2016 m. - 22 atvejai) Seimo rinkimu pirmuosiuose turuose lèmè rinkejų aktyvus balsavimas už daugiamandatės apygardos partijų sąrašus ir santykinai gerokai mažiau populiarūs jų vienmandačių kandidatai (žr. 1 lentelę). Tuo DP ir LVŽS išsiskiria iš kitų partijų, kur dažniau matome atvirkštinę tendenciją (populiaresni vienmandačių apygardų kandidatai, o sąrašai - mažiau populiarūs). Tiesa, $2016 \mathrm{~m}$. Seimo rinkimų antrajame ture dalyvavę LVŽS kandidatai dažniausiai aplenkẻ pirmojo turo nugalètojus (pirmiausia TS-LKD ir LSDP kandidatus). Tai akivaizdu Kauno m., taip pat Dzūkijos (Nr. 69), Garliavos (Nr. 66), Vilkaviškio (Nr. 68), Tauragès (Nr. 34), Biržų-Kupiškio (Nr. 48) vienmandatèse rinkimų apygardose. Bendrai tokia situacija rodo, kad, išskyrus LVŽS ir DP lyderius, šios partijos neturèjo pakankamai stiprių, visuomenei gerai žinomų kandidatų. LVŽS remiamų kandidatų sèkmé 2016 m. Seimo rinkimu antrajame ture pirmiausia sietina ne su jų pačių, o politinès jègos, kuriai jie atstovavo (LVŽS), ir šios partijos lyderių populiarumu. Apklausų duomenys (Jastramskis, 2018b; Morkevičius, 2018) taip pat rodo, kad LVŽS, kaip antrasis pasirinkimas, buvo patraukli i̇vairių partijų rinkejjams (LSDP, TS-LKD ir t. t.). Tuo tikrai negali pasigirti jokia kita ịtakingesne Lietuvos partija (ypač TS-LKD). Iš esmès tai ir garantavo net mažai visuomenèje žinomų LVŽS remiamų politikų pergalę $2016 \mathrm{~m}$. Seimo rinkimų antrajame ture.

Apibendrinant tikslinga pabrèžti, kad nors Lietuvos rinkèjų politinès preferencijos santykinai dažniau būna nuoseklios - rinkimuose balsuojama už konkrečios partijos daugiamandatès apygardos sąrašą ir tos pačios partijos remiamą kandidatą, tačiau padalyto balsavimo atvejų skaičius taip pat yra gana didelis, o tiriamaisiais 2012-2016 m. jis net išaugo (žr. 1 lentelę). Tad kalbèti apie Lietuvos partinès sistemos stabilizaciją yra dar ankstoka - pastaruoju metu stebimas atvirkštinis procesas. Padalyto balsavimo atvejų skaičiaus augimas yra ne vienintelis partinès sistemos nestabilumo požymis. Dar geriau tai iliustruoja nemenkai provincijos rinkimų apygardu daliai būdinga nuolatiné rinkèjų politinių preferencijų kaita. Tuo tarpu Vilniaus m., Pietryčių 

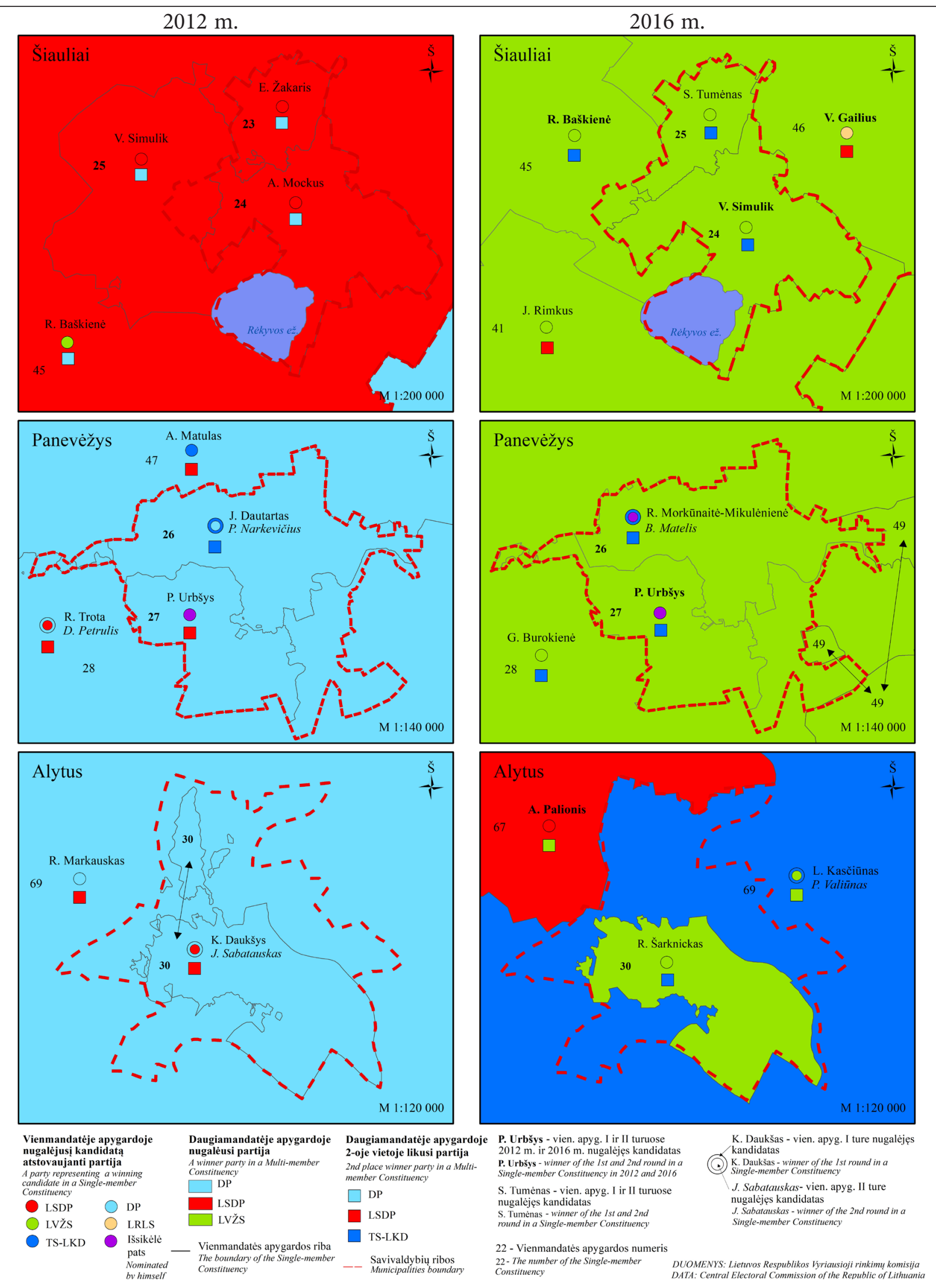

3 pav. 2012 ir 2016 m. Seimo rinkimų (Šiaulių, Panevėžio ir Alytaus miestų) vienmandatėse apygardose nugalèję kandidatai ir pirmavę partijų sąrašai (Duomenys: Lietuvos Respublikos Vyriausioji rinkimų komisija)

Fig. 3. Winners and party lists of the 2012 and 2016 Seimas elections in the Single-member Constituencies (Šiauliai, Panevezzys and Alytus cities) (Data: Central Electoral Commission of the Republic of Lithuania) 
Lietuvos ir kai kurių kitų atskirų vienmandačių apygardų rinkejjams būdingos gerokai stabilesnès politinès preferencijos. Tai yra tos apygardos, kuriose rinkejjai aktyviausiai balsuoja už LLRA ir TS-LKD. Šių partijų rèmėjai Vilniaus mieste ir visame Pietryčių Lietuvos regione jau seniai iš bendro Lietuvos konteksto išsiskiria politinių preferencijų stabilumu bei pakankamai nuoseklia parama LLRA ir TS-LKD - joms būdingas santykinai mažas padalyto balsavimo atvejų skaičius. Nuosekliai rinkimuose balsuoja ir Šiaulių rinkejjai, tačiau jų politinès preferencijos iki šiol buvo palankesnès LSDP (2012 m. ir anksčiau) ir LVŽS (2016 m.) (žr. 3 pav.). Dažniausiai provincijų vienmandatėse rinkimų apygardose, kuriose aktyviausiai balsuota už DP (2012 m.) ir LVŽS (2016 m.), stebima santykinai daugiausia padalyto balsavimo atvejų. Staiga iškilusios politinès jègos neturi pakankamo skaičiaus visuomenei gerai žinomų ir patyrusių politikų. Tai prisideda prie rinkejų nusivylimo išrinktaisiais ir skatina per kitus rinkimus balsuoti vẻl už kitas „gelbètojų" partijas. Štai toks politinis ciklas tęsiasi metai po metų, neleisdamas stabilizuotis rinkejjų politinèms preferencijoms, o kartu ir visai šalies partinei sistemai. Be to, pirmųjų rinkimų turų rezultatai rodo, jei Lietuvoje būtų taikoma britiškojo tipo vieno turo mažoritarinè („pirmas prie finišo“) rinkimų sistema, tai akivaizdu, kad ji būtų palankiausia tradicinių partijų, pirmiausia TS-LKD ir LSDP, remiamiems kandidatams (žr. 1 pav.).

\section{PARTIJŲ IR KANDIDATŲ İTAKOS SANTYKIS CENTRO-PERIFERIJOS PJŪVIU}

Rinkimų apylinkèse analizuojant vienmandačių kandidatų ir jiems atstovaujančių partijų sąrašų proporcinejje rinkimų dalyje tarpusavio ryšį, galima išskirti tam tikrus regioninius aspektus, tačiau skirtumai nèra itin raiškūs. 2016 m. Seimo rinkimų pirmajame ture mažiausia padalyto balsavimo atvejų (daugiausia rinkejų balsų gavo konkrečiai partijai atstovaujantis vienmandatès apygardos kandidatas ir tos pačios partijos daugiamandatès apygardos sąrašas) būta Pietryčių, kiek mažiau - Centrinèje ir Pietų Lietuvoje (žr. 4 pav.). Kaip atskiras arealas išsiskyrè rytinè Žemaitijos dalis, taip pat kai kurios kitų regionų savivaldybės (Ignalinos r., Kupiškio r., Pane- vėžio r., Šilutės r., Pagègių). Tai sietina su dalyje savivaldybių ar net regionų jau nebe pirmi rinkimai įsitvirtinusiu didžiuliu kai kurių politinių jègų populiarumu. Pietryčių Lietuvoje (Šalčininkų r., Vilniaus r. (išskyrus Vilniaus priemiesčius), pietinejje Švenčionių r., kai kuriose periferinėse gretimų savivaldybių rinkimų apylinkèse, kuriose dominuoja lenkų tautybès rinkejjai) tai lèmé didžiulis šiame regione LLRA populiarumas. Daugumoje Vilniaus m. ir Kauno m. rinkimų apylinkių - TS-LKD. Kitose savivaldybèse, kuriose stebimas mažesnis padalyto balsavimo atvejų skaičius, išsiskiria dažniausiai prieš $2016 \mathrm{~m}$. labai išaugęs LVŽS ir šios partijos kandidatų populiarumas. Tai itin ryšku tose savivaldybèse, kuriose ir anksčiau LVŽS buvo santykinai gana populiari (Šiaulių r. ir m., Ignalinos r., Kupiškio r. ir kt.), kai kuriose savivaldybėse LVŽS populiarumas stipriai išaugo dèl sumenkusio LSDP ar DP populiarumo (Marijampolès, Kelmès r.). Ir tik nedaugelyje savivaldybių tvirtas pozicijas (išvengiant padalyto balsavimo) išlaike kitos partijos: Visagino, Pagègių ir Šilalès r. - PTT; Širvintų r. - DP; Birštono ir didele dalimi Prienų r. bei Tauragès r. - LSDP; daugumoje Palangos, Moletų r. rinkimų apylinkių - TS-LKD. Taigi, rinkimų apylinkèse išryškejo savotiški partijų populiarumo teritoriniai branduoliai, kuriems jau nebe pirmi rinkimai būdingas stabiliai aukštas tam tikrų politinių jègų ir joms atstovaujančių vienmandačių kandidatų populiarumas. Stiprus kandidatas suteikia papildomų dividendų ir partijos, kuriai jis atstovauja, sąrašui. Tokiose apygardose pirmaujančios partijos ir joms atstovaujantys kandidatai gyventojų turètų būti suvokiami kaip iprasti ir savi. Be to, šiose savivaldybèse populiarios partijos yra taip aktyviai remiamos gyventojų, kad susidaro įspūdis, jog iš esmès bet kuris vienmandatẻje kandidatuojantis tų partijų remiamas kandidatas be didesnių asmeninių pastangų pajègus nugalèti rinkimuose (tai ypač akivaizdu tose savivaldybèse, kuriose populiariausia yra LLRA).

Vienareikšmiai teigti, kad daugumai iš prieš tai aptartų savivaldybių visų tipų rinkimų apylinkèms (žr. tyrimo metodologiją) būdingas aukštas jų rinkejjų politinių preferencijų panašumas, negalima, nes labai dažnai skiriasi savivaldybių centrų ir kaimiškų apylinkių rinkejjų politinès preferencijos. Išimtis tik Pietryčių Lietuva (populiariausia LLRA) (išskyrus Vilniaus $\mathrm{m}$. priemiestines 
apylinkes), Šiaulių m. ir r., Ignalinos r. (LVŽS), Visagino (PTT), Birštono (LSDP) savivaldybès, kuriose nepriklausomai nuo rinkimų apylinkių tipo dominuoja konkrečios politinès partijos daugiamandatès apygardos sąrašai ir jos remiami vienmandačių apygardų kandidatai.

Daugumoje Lietuvos savivaldybių rinkèju politinių preferencijų skirtumai tarp jų centrų ir kaimiškų rinkimų apylinkių išlieka gana ryškūs. Pavyzdžiui, Plungès r. sav. kaimiškose apylinkèse $2016 \mathrm{~m}$. Seimo rinkimu pirmajame ture pirmavo LVŽS sąrašas ir kandidatas, o pačioje Plungeje - LRLS kandidatas; Pasvalyje, Molètuose, Utenoje - TS-LKD sąrašas ir kandidatas, o daugumoje tų pačių savivaldybių kaimiškų apylinkių - LVŽS sąrašas (o dažnai - ir kandidatas); Taurageje, Jonavoje - LSDP sąrašas ir kandidatas, o šių savivaldybių periferijoje - dažnai LVŽS sąrašas. Panaši situacija būdinga daugumai Lietuvos savivaldybių. Taip pat iš bendro didmiesčius juosiančių „žiedinių“ savivaldybių dažnai išsiskiria priemiestinès rinkimų apylinkès, kuriose dèl sparčios suburbanizacijos (Savickaitè ir kt., 2013; Baranauskaitè ir kt., 2015) anksčiau dažniausiai centro kairiųjų politinių jègų dominuojamoje teritorijoje atsiranda vis daugiau rinkimu apylinkių, kuriose rinkimuose pirmauja centro dešiniųjų partijų sąrašai ir kandidatai (dažniausiai - TS-LKD). Ši tendencija itin ryški Vilniaus metropoliniame regione.

Toliau tikslinga aptarti pagrindinių Lietuvos partijų populiarumo skirtumus skirtingo tipo rinkimų apylinkėse (žr. 4 pav.).

LVŽS daugiamandatès apygardos sąrašas ir jos deleguoti vienmandačių apygardų kandidatai pirmajame ture pirmavo net ketvirtadalyje (524 iš 1 995) rinkimų apylinkių. Tačiau dažniausiai tai nedidelès kaimiškos rinkimų apylinkès, nes didejjant gyvenviečių kategorijai (nuo kaimiškų rinkimų apylinkių link miesto), ne tik mažèjo LVŽS populiarumas, bet ir vis dažniau LVŽS pergalè buvo vienpusiška - partijos sąrašui pirmaujant daugiamandatès apygardos apylinkèse, vis dažniau tose pačiose vienmandatès apygardos apylinkèse pirmajame ture nugalejo kitu partijų kandidatai - t. y. padalyto balsavimo atvejų skaičius ženkliai išaugo. Kaimiškose ir miestelių bei didesnių gyvenviečių rinkimų apylinkèse situacija panaši - kaimiškose rinkimų apylinkèse LVŽS sąrašas ir šios partijos remiamas kandi- datas kartu pirmavo net 226 apylinkèse (tai sudaro 32,33 \% visų kaimiškų apylinkių), o miestelių ir didesnių gyvenviečių kategorijoje - 98 apylinkèse (tai sudaro 30,43\% visų miestelių ir didesnių gyvenviečių apylinkių, kuriose rinkejjų sąrašuose yra 30,49 \% tos kategorijos apylinkiu rinkejjų). Tuo tarpu mažųjų ir vidutinių miestų (per 5 tūkst. gyv.) rinkimų apylinkių kategorijose LVŽS sąrašui ir šios partijos deleguotiems kandidatams sekèsi gerokai prasčiau. LVŽS sąrašas ir jos deleguoti kandidatai kartu mažųų miestų kategorijoje pirmajame rinkimų ture pirmavo tik 9 rinkimų apylinkèse $(16,98 \%$ visų mažųjų miestų rinkimų apylinkių, kuriuose buvo 15,15 \% visų šiai kategorijai priskirtų apylinkių rinkejjų). Vidutinių miestų kategorijoje tokių apylinkių buvo 29 $(10,98 \%$ su $11,42 \%$ visų šiai kategorijai priskirtų apylinkių rinkèjų).

Nors ir nèra dèsninga, tačiau priemiesčiu ir didžiųjų miestų apylinkių kategorijoje rinkimų apylinkių, kuriuose $2016 \mathrm{~m}$. Seimo rinkimų pirmajame ture pirmavo LVŽS sąrašas ir šiai partijai atstovaujamas kandidatas, vèl kiek išaugo - priemiesčių rinkimų apylinkèse LVŽS sąrašas ir kandidatas kartu pirmavo 83 rinkimu apylinkèse $(29,54 \%$ visų šiai kategorijai priskirtų apylinkių skaičiaus, kuriose buvo $25,85 \%$ visų šiai kategorijai priskirtų apylinkių rinkejų). Didžiųjų miestų - atitinkamai 79 rinkimų apylinkèse $(20,95 \%$ apylinkių, 20,13 \% rinkèjų). Didžiausios įtakos tokiems gana netikètiems LVŽS pasiekimams urbanizuotose teritorijose turejo didelis šios partijos populiarumas Šiaulių (pvz., Šiaulių m. beveik visose (išskyrus 1) rinkimų apylinkèse pirmavo LVŽS sąrašas ir vienmandatès kandidatas), kiek mažesnis - Kauno, Panevėžio ir Alytaus metropolinių regionų rinkimų apylinkèse. Vilniaus ir Klaipèdos rinkimų apylinkèse situacija kardinaliai priešinga - LVŽS šiuose miestuose nebuvo populiari, jos deleguoti vienmandačiu apygardu kandidatai pirmajame ture pirmavo tik kai kuriose apylinkèse, sutampančių apylinkių (kuriose pirmavo LVŽS sąrašas ir šios partijos vienmandatès kandidatas) Vilniuje iš viso nèra, o Klaipèdoje tik keturi.

Apibendrinant pažymėtina, kad LVŽS iš visu kitų partijų išsiskyrè tuo, kad daugiamandatès apygardos apylinkèse pirmaujant LVŽS sąrašui itin dideleje apylinkių dalyje vienmandatèse apygardose pirmajame rinkimų ture daugiausia 


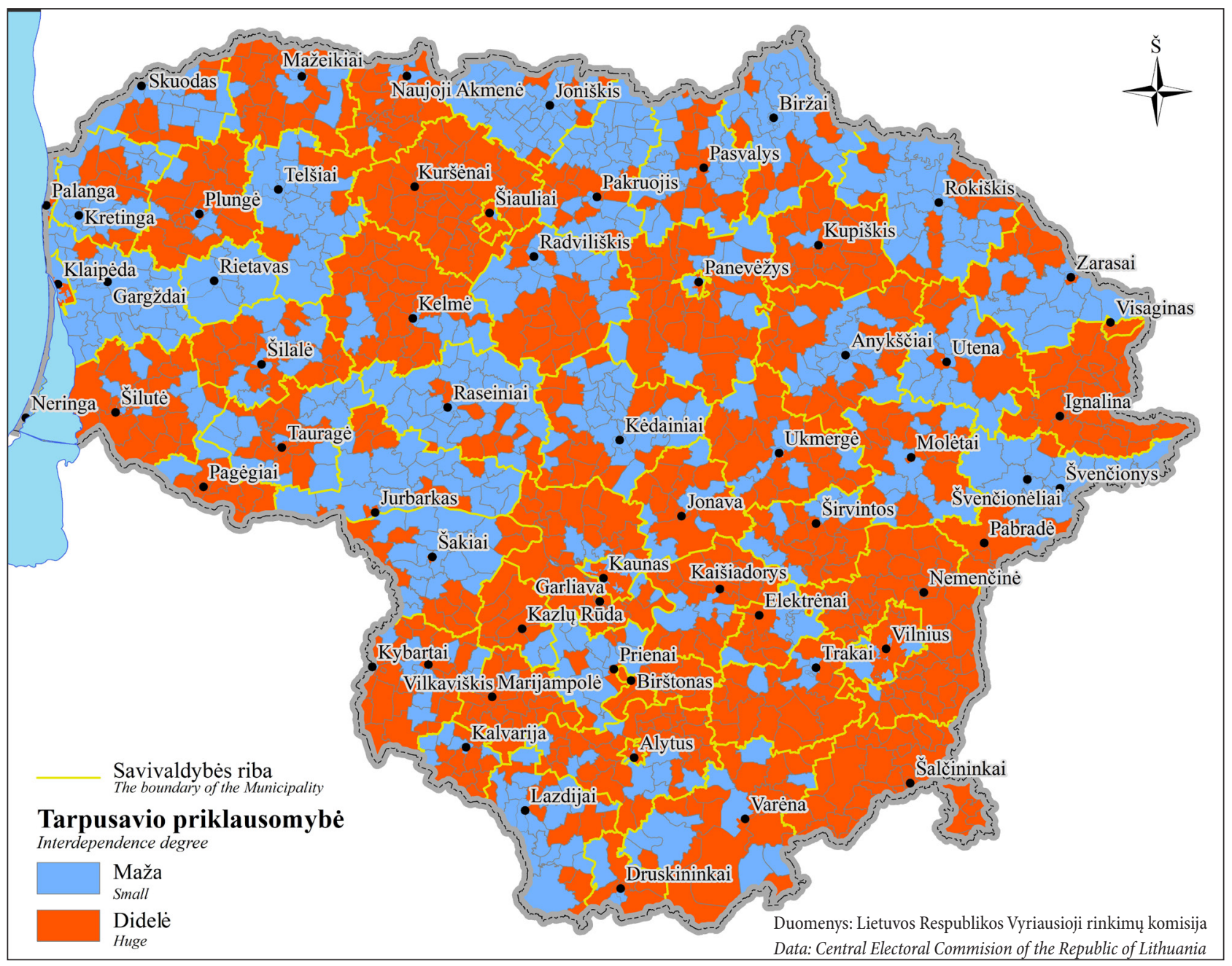

4 pav. Kandidato ir jo atstovaujamos partijos populiarumo tarpusavio priklausomybė mažoritarinio (daugumos) ir proporcinio atstovavimo lygmeniu

Fig. 4. The interdependence of the popularity of the candidate and the party he/she represents at the level of minority (majority) and proportional representation

balsų gavo kitų partijų kandidatai. Galima teigti, kad LVŽS, gana didelị visuomenès palaikymą turẻjusiai partijai, stigo visuomeneje geriau žinomų vienmandačių apygardų kandidatų.

Didžia dalimi priešinga (nei LVŽS) situacija stebima rinkimų apylinkèse lyginant TS-LKD sąrašo daugiamandateje ir šios partijos remiamų kandidatų vienmandatèse rinkimų apygardose pirmojo turo rezultatus. Mažejant urbanizacijos lygiui (nuo didžiųjų miestų rinkimų apylinkių link kaimiškų), gana ženkliai mažeja TS-LKD populiarumas. Itin didelio rinkèjų palaikymo tiek partijos sąrašas, tiek jai atstovaujantis kandidatas sulauke didžiuosiuose miestuose. Iš 377 didžiųjų miestų rinkimų apylinkių TS-LKD sąrašas ir šios partijos deleguotas vienmandatès kandidatas pirmajame rinkimų ture pirmavo 174 apylinkèse, tai sudaro net $46,15 \%$ visų šiai kategorijai priskirtų apylinkių. Galima daryti išvadą, kad didmiesčiu gyventojų preferencijos TS-LKD partijai yra gana nuoseklios ir stabilios, o partijos kelti kandidatai TS-LKD elektoratui buvo priimtini. Šiuo aspektu iš Lietuvos didžiųjų miestų išsiskyrè Vilniaus m. rinkimų apylinkès - TSLKD ir jai atstovaujantis kandidatas pirmajame ture daugiausia balsų gavo net 99 rinkimu apylinkèse, tai sudaro 68,28 \% visų šiai kategorijai priskirtu Vilniaus m. (145 apyl.) rinkimų apylinkių, Kauno m. (46 iš 91 apyl.) - 50,55 \%, Klaipèdos m. (19 iš 54 apyl.) - 35,19\%, Panevèžio m. (8 iš 29 apyl.) - 25,59 \%, Alytaus m. (2 iš 24 apyl.) $-8,33 \%$. Šiauliuose TS-LKD tradiciškai nebuvo populiari nei daugiamandateje, nei vienmandatèse apygardose (0 iš 34 apyl.). Taigi, kuo 
mažesnis didmiestis, tuo TS-LKD ir jos kandidatų santykinis populiarumas mažesnis ir rinkëjų politinès preferencijos šiai partijai yra vis mažiau nuoseklios. Šis dèsningumas būdingas ne tik didžiųjų miestų, bet ir visų kitų kategorijų rinkimų apylinkėms. Mažejat gyvenviečių kategorijai, mažeja ir rinkejuc politinès preferencijos TS-LKD sąrašui ir jos remiamam kandidatui, taip pat ir šios paramos nuoseklumas (t. y. daugejja padalyto balsavimo atvejų). Jei didžiųjų miestų rinkimų apylinkių kategorijoje nuoseklios rinkejų politinès preferencijos TS-LKD sąrašui ir kandidatui siekè net $46,15 \%$ visų šiai kategorijai priskirtų apylinkių, tai vidutinių miestų (per 5 tūkst. gyv.), priemiesčių ir mažųjų miestų kategorijose jis varijavo nuo 12,10 iki 13,21 \% visų šioms kategorijoms priskirtų rinkimų apylinkių. Dar mažesnis paramos TS-LKD sąrašui ir jos remiamam kandidatui nuoseklumas fiksuotas kaimiškų, miestelių ir didesnių gyvenviečių rinkimų apylinkių kategorijose. Miestelių ir didesnių gyvenviečių kategorijoje TS-LKD daugiamandatès apygardos sąrašas ir jos deleguotas vienmandatès apygardos kandidatas pirmajame ture daugiausia balsų gavo 20 rinkimų apylinkių (6,21\%) iš 322 šiai kategorijai priskirtų apylinkių, kaimiškų apylinkių kategorijoje - 50 apylinkių (7,15\%) iš 699 šiai kategorijai priskirtų apylinkių.

Vertinant su TS-LKD susijusius padalyto balsavimo atvejus pirmajame rinkimų ture skirtingų kategorijų rinkimų apylinkèse pastebima dar viena įdomi ir gana désninga tendencija - didžiųjų miestų, priemiesčių ir vidutinių miestų rinkimų apylinkių kategorijose santykinai dažniau pirmavo TS-LKD sąrašas, o šios partijos deleguoti vienmandačių apygardų kandidatai buvo mažiau populiarūs, ir priešingai - mažųjų miestų, miestelių bei didesnių gyvenviečių ir kaimiškų apylinkių kategorijose santykinai didesneje joms priskirtų apylinkių dalyje daugiausia balsų gavo TS-LKD deleguoti vienmandačių apygardų kandidatai, tačiau už TS-LKD sąrašą populiaresni buvo kitų partijų daugiamandatès apygardos sąrašai. Didžiųjų miestų kategorijoje 78 rinkimų apylinkèse pirmaujant TS-LKD sąrašui, daugiausia balsų gavo kitų partijų arba nepriklausomi vienmandačių apygardų kandidatai. Priešinga situacija, kai pirmaujant kitų partijų daugiamandatės apygardos sąrašui tose pat apylinkèse pirmajame ture daugiausia balsų gavo TS-LKD vienmandačių apygardų kandidatai, fiksuota tik 15 rinkimų apylinkių. Vidutiniu miestu kategorijoje - atitinkamai 33 apylinkès (pirmavo TS-LKD sąrašas) ir 29 apylinkès (daugiausia balsu gavo TS-LKD vienmandačių apygardų kandidatai), priemiesčiu kategorijoje - atitinkamai 23 apylinkès ir 18 apylinkių. Kaip jau buvo minèta, priešingos tendencijos fiksuotos žemesnių kategorijų rinkimų apylinkėse. Pavyzdžiui, kaimiškų apylinkių kategorijoje 18 rinkimų apylinkių (iš 699) pirmavus TS-LKD sąrašui, pirmajame ture daugiausia rinkejjų balsų gavo kitų partijų arba nepriklausomi vienmandačių apygardų kandidatai. Priešinga situacija, kai pirmavus kitų partijų daugiamandatès apygardos sąrašui (dažniausiai LVŽS) tose pat apylinkèse daugiausia rinkejjų balsų gavo TSLKD vienmandačiu apygardu kandidatai, fiksuota jau 50 rinkimų apylinkių (iš kurių net 43 pirmavo LVŽS daugiamandatès apygardos sąrašas). Miestelių ir didesnių gyvenviečių kategorijoje 10 apylinkių pirmavo tik TS-LKD daugiamandates apygardos sąrašas, o 39 apylinkèse - tik TS-LKD deleguoti vienmandačių apygardų kandidatai (visose 39 apylinkèse pirmavo LVŽS daugiamandatès apygardos sąrašas). Tokios tendencijos, kai visose miestelių ir didesnių gyvenviečių kategorijos rinkimų apylinkèse ir daugumoje kaimiškų rinkimų apylinkių, kuriose vienmandateje apygardoje pirmajame rinkimų ture pirmavo TS-LKD kandidatas, o daugiamandatèje apygardoje - LVŽS sąrašas, tik patvirtina prielaidą, kad provincialesnèse vietovèse TS-LKD ir LVŽS elektoratas dažnai persidengia, nes kaimiškose vienmandatèse apygardose santykinai dažniau kandidatavo TSLKD krikdemiškojo sparno atstovai, kurių pažiūros daugeliu aspektų artimos LVŽS politinèms nuostatoms. Tad nemenkos šių apylinkių rinkejjų dalies politinès preferencijos abiems partijoms yra panašios. Be to, tai taip pat rodo, kad LVŽS $2016 \mathrm{~m}$. Seimo rinkimuose neturejo pakankamai žinomų ir įtakingų asmenybių, o TS-LKD šiuo požiūriu buvo gerokai pranašesnè.

Kitos partijos $2016 \mathrm{~m}$. Seimo rinkimuose ne tik buvo gerokai mažiau populiarios nei LVŽS ir TS-LKD, tačiau ir rinkejjų politinès preferencijos joms dažnai nebuvo dèsningos ir nuoseklios (išskyrus Pietryčių Lietuvoje itin populiarią LLRA). Tačiau trumpai ir jas verta aptarti.

Nors didžiųjų miestų kategorijos rinkimų apylinkèse tiek daugiamandateje, tiek vienmandatèse 
rinkejų parama buvo skirta įvairioms partijoms ar joms atstovaujantiems kandidatams, tačiau LSDP šioje kategorijoje tarp rinkejjų nebuvo populiari - tik vienoje Šiauliu m. apylinkeje pirmavo LSDP kandidatas (A. Mockus Šimšès rinkimų apylinkèje), o daugiamandatèje visose didžiųjų miestų rinkimų apylinkèse pirmavo kitų partijų sąrašai. Nuosekliausios rinkèjų politinès preferencijos LSDP nustatytos vidutinių ir mažų miestų kategorijose. Vidutinių miestų kategorijoje LSDP daugiamandatès apygardos sąrašas ir šios partijos remiami vienmandačių apygardų kandidatai pirmavo 44 apylinkèse, tai sudaro $16,37 \%$ visų šiai kategorijai priskirtų apylinkių, o mažųjų miestų kategorijoje -8 apylinkèse $(15,09 \%$ visų šios kategorijos apylinkių). Taigi, kai kurių (bet tik nedidelès dalies) mažųjų ir vidutinių miestų rinkejai, kaip ir ankstesniuose rinkimuose, išliko svarbiausia paramos LSDP baze. Dvigubai mažesnio populiarumo LSDP sulaukè likusiose trijose kategorijose - priemiesčių, miestelių ir didesnių gyvenviečių bei kaimiškų apylinkių. Čia LSDP partijos sąrašo daugiamandateje apygardoje ir jai atstovaujančių vienmandačių apygardų kandidatų pergale tose pat apylinkèse („nugalètojai sutampa") varijavo nuo $7,12 \%$ iki $8,87 \%$ visų toms kategorijoms priskirtų rinkimų apylinkių.

LSDP iš visų partijų išsiskyre tuo, kad itin didelejje rinkimų apylinkių dalyje pirmajame rinkimų ture daugiausia balsų gavus šios partijos remiamiems vienmandačiu apygardų kandidatams, tose pačiose apylinkèse pirmavo kitų partijų ar jų koalicijų daugiamandatès apygardos sąrašai. Visose rinkimų apylinkių kategorijose pastebimos žymiai didesnès rinkèjų politinès preferencijos LSDP deleguotiems vienmandačių apygardų kandidatams nei pačios partijos daugiamandatès apygardos sąrašui. Kaip jau buvo minèta, didžiųjų miestų apylinkių kategorijoje LSDP remiamas vienmandatès apygardos kandidatas nugalèjo tik vienoje rinkimų apylinkejje (Šiaulių m.), o šios partijos sąrašas patyrè nesèkmę visose rinkimų apylinkèse. Vidutinių miestų kategorijoje LSDP vienmandačių apygardų kandidatai pirmajame rinkimų ture pirmavo 29 rinkimų apylinkèse (kuriose pirmavo kitų partijų sąrašai), kai LSDP daugiamandatès apygardos sąrašas pirmavo tik 10 rinkimų apylinkių (kuriose pirmavo kitų partijų deleguoti ir nepriklausomi vienmandačių apygardų kandidatai). Priemiestinių apylinkių kategori- joje šis santykis buvo atitinkamai 22 ir 5 apylinkès, mažųjų miestų kategorijoje - 7 ir nei vienos apylinkès, miestelių ir didesnių gyvenviečių kategorijoje - 33 ir viena apylinkè, kaimiškų rinkimų apylinkių kategorijoje - 59 ir 12 apylinkių. Tose apylinkèse, kuriose rinkimų pirmajame ture pirmavo LSDP remiami vienmandačių apygardų kandidatai, daugiamandateje apygardoje labai aiškiai $(87,4$ \%) dominavo LVŽS daugiamandatès apygardos sąrašas. Tai patvirtina prielaidą, kad $2016 \mathrm{~m}$. Seimo rinkimuose LVŽS buvo ta politinè jèga, kuri sugebejjo pervilioti didelę dali potencialaus LSDP elektorato. LSDP vienmandatèse apygardose panaudojo turimą asmenybini potencialą, tačiau tai nepadejo partijai pasiekti geresnių rezultatų daugiamandateje apygardoje.

Lietuvos Respublikos liberalų sąjūdžiui (LRLS) 2016 m. Seimo rinkimai nebuvo itin sèkmingi. Gana ženkliai šios partijos ir jos remiamų vienmandačių apygardų kandidatų populiarumas smuko daugumoje didžiụjų miestų ir jų priemiesčių rinkimų apylinkių. O juk šių kategorijų rinkimų apylinkių rinkejjai buvo pagrindiniai LRLS rèmejjai. Nors LRLS vienmandačių apygardų kandidatai pirmajame ture daugiausia balsų gavo 16 didžiųjų miestų $(4,24 \%)$ ir 18 priemiesčių $(6,41 \%)$ rinkimų apylinkių, tačiau šios partijos sąrašas nebuvo pirmaujantis nei vienoje iš šių kategorijų rinkimų apylinkių (ir mažųjų miestų kategorijoje). 2016 m. buvo kelios rinkimų apylinkès, kuriose rinkejjai aktyviausiai balsavo ne tik už LRLS remiamą kandidatą, bet ir už jos sąrašą („nugalètojai sutampa“), iš kurių vidutinių miestų kategorijoje tokia buvo tik viena rinkimu apylinkè $(0,38 \%$ visų šios kategorijos apylinkių), miestelių ir didesnių gyvenviečiuc - trys apylinkès $(0,93 \%)$ ir kaimiškų apylinkių kategorijoje - 10 apylinkių $(1,43 \%)$. Be to, Lietuvoje nebuvo nei vienos rinkimų apylinkès, kurioje būtų pirmavęs LRLS daugiamandatès apygardos sąrašas, vienmandateje apygardoje daugiausia balsų gavus kitos partijos atstovui. Tai patvirtina prieš tai išsakytą teiginį, kad LRLS šiuose rinkimuose nebuvo populiari, tačiau partija turejjo kelis įvairiose vienmandatèse apygardose itin sèkmingus kandidatus, kurie padidino ir LRLS sąrašo („apkrètimo efektas") populiarumą regionuose (Plungès (Nr. 35), Žiemgalos (Nr. 46), Trakų-Vievio (Nr. 58) Varènos-Trakų (Nr. 70) vienmandatès rinkimų apygardos). 
Jau tradiciškai ypač ryškiu rinkejuç politiniu preferenciju nuoseklumu išsiskyrè Lietuvos lenkų rinkimų akcija - Krikščioniškų šeimų sąjunga (LLRA). Ši regioninè Lietuvos partija itin populiari Pietryčių Lietuvoje, o kituose Lietuvos regionuose visiškai neịtakinga. Tad šios partijos populiarumo duomenis analizuoti visos Lietuvos rinkimų apylinkių kontekste nèra prasminga. Svarbiau ìvertinti rinkejjų politinių preferencijų šiai partijai nuoseklumą tik Pietryčių Lietuvos regione. Panašiai kaip ir LVŽS ir priešingai nei visų kitų partijų atvejais, $2016 \mathrm{~m}$. Seimo rinkimų pirmajame ture LLRA daugiamandatès apygardos sąrašui rinkimų apylinkèse sekèsi šiek tiek geriau nei šios partijos remiamiems kandidatams. Iš viso LLRA daugiamandatès apygardos kandidatu sąrašas pirmavo 123 rinkimų apylinkèse, o šios partijos remiami vienmandačių apygardų kandidatai - 110 rinkimų apylinkių. Iš jų abipusè pergalè („nugalètojai sutampa“) pirmajame rinkimų ture pasiekta 109 rinkimų apylinkèse: keturiose Vilniaus miesto, devyniose vidutinių miestų, 28 priemiesčių, 16 mažųjų miestų, 18 miestelių ir didesnių gyvenviečių bei 44 kaimiškose rinkimų apylinkèse. Dar 14 rinkimų apylinkių, iš kurių net 11 yra Vilniaus m., pirmavo tik LLRA sąrašas, ir tik vienoje rinkimų apylinkejje - šios partijos deleguotas vienmandatés apygardos kandidatas (daugiamandatèje pirmavo TS-LKD sąrašas). Taigi, LLRA rinkejjai, dažniausiai lenkų tautybès Lietuvos piliečiai, nors ir susitelkę tik viename nedideliame Lietuvos regione, tačiau pasižymi išskirtiniu lojalumu regioninei / tautinei partijai - LLRA, jų politinès preferencijos šiai partijai itin nuoseklios, o gana aukštas rinkiminis aktyvumas padeda pasiekti gana neblogų rezultatų. Panašiai kaip ir LVŽS, šiai partijai atstovaujančių vienmandačių apygardų kandidatų indèlis nèra svarbus, nes LLRA rinkejai pirmiausia balsuoja už „savo" regioninę / tautinę partiją.

Likusios dvi tradiciškai įtakingesnès Lietuvos partijos - Darbo partija (DP) ir Partija „Tvarka ir teisingumas" (PTT) $2016 \mathrm{~m}$. Seimo rinkimuose buvo mažiau populiarios (ypač DP) nei ankstesniuose Seimo rinkimuose, be to, abi partijos išsiskyrè regionuose gana netolygiomis rinkejų politinėmis preferencijomis jų daugiamandatès apygardos sąrašams ir vienmandačių apygardų kandidatams. 2016 m. Seimo rinkimuose jos priminè regionines partijas, tačiau regionų iš es- mès nesudarè, nes santykinai didesniu šių partijų populiarumu išsiskyrè skirtingose Lietuvos dalyse esančios vienmandatès rinkimų apygardos (DP: Molètų-Širvintų (Nr. 54), iš dalies Telšių (Nr. 40) ir Kèdainių (Nr. 43); PTT: Pietų Žemaitijos (Nr. 33), Visagino-Zarasų (Nr. 52), iš dalies Gargždų (Nr. 31) ir Mažeikių (Nr. 38)). Tačiau, skirtingai nei LLRA, iš tiesų tai nèra regioninès partijos, nes tam tikrą rinkejų palaikymą turi ir visose kitose (išskyrus Pietryčiu Lietuvą) vienmandatèse rinkimų apygardose.

Priešingai nei LLRA ir LVŽS, DP ir PTT sèkmè kai kuriose vienmandatèse rinkimų apygardose pirmiausia buvo nulemta ne šių partijų, o kai kurių jų deleguotų vienmandačių apygardų kandidatų populiarumo. Tuo tarpu jų daugiamandatès apygardos sąrašai buvo mažiau populiarūs: PTT sąrašas, gavęs 5,33 \% rinkimuose dalyvavusių rinkèjų balsų, sugebejjo įveikti $5 \%$ barjerą, o DP sąrašui, už kurị balsavo tik $4,68 \%$ rinkejjų, to padaryti nepavyko.

DP deleguoti vienmandačių apygardų kandidatai pirmajame rinkimų ture pirmavo 141 rinkimų apylinkejje (dažniausiai nedaug rinkejjų turinčiose kaimiškose apylinkèse). DP daugiamandatès apygardos sąrašas - 40 rinkimų apylinkių. Kartu DP daugiamandatès apygardos sąrašas ir jos remiami vienmandačių apygardų kandidatai pirmavo 33 rinkimų apylinkèse. Iš jų 18 kaimiškų apylinkių $(2,58 \%$ visų šiai kategorijai priskirtų rinkimų apylinkių), 8 miestelių ir didenių gyvenviečiu apylinkėse (2,48\%), kitose kategorijose DP buvo dar mažiau populiari - nugalèjo 1-3 apylinkèse (nuo 1 iki $2 \%$ ), o didžiųjų miestų nei vienoje.

Panaši situacija būdinga ir PTT. Šios partijos deleguoti vienmandačių apygardų kandidatai pirmajame rinkimų ture pirmavo 87 rinkimų apylinkèse, o PTT daugiamandatès apygardos sąrašas - 54 rinkimų apylinkèse. Kartu PTT daugiamandatès apygardos sąrašas ir jos remiami vienmandačių apygardu kandidatai pirmavo 48 rinkimų apylinkèse. Iš jų santykinai daugiausia - 16 vidutinių miestų apylinkių $(6,06 \%$ visų šiai kategorijai priskirtų rinkimų apylinkių). Tačiau visos 16 šios kategorijos apylinkès priklauso Visagino sav., kuri tapo savotiška didesnio PTT populiarumo „sostine““. Be to, visos Visagino rinkimų apylinkès rinkejjų skaičiumi yra maždaug dvigubai mažesnès, palyginti su kitomis Lietuvos 
2 lentelè. Rinkèjų politinių preferencijų nuoseklumas rinkimų apylinkių kategorijose (pagal paramą kandidatui vienmandatès ir $\mathrm{jị} \mathrm{delegavusios} \mathrm{partijos} \mathrm{sąrašui} \mathrm{daugiamandatẻs} \mathrm{apygardos} \mathrm{apylinkėse)}$

Table 2. Consistency of voters' political preferences in polling districts (based on support for the candidate's list of Single-member Constituencies and the delegating party's list in Multi-member Constituency)

\begin{tabular}{c|c|c|c}
\hline $\begin{array}{c}\text { Rinkimų apylinkiu kategorijos } \\
\text { Polling districts }\end{array}$ & $\begin{array}{c}\text { Rinkimų } \\
\text { apylinkių } \\
\text { skaičius } \\
\text { Polls }\end{array}$ & $\begin{array}{c}\text { "Nugalètojai } \\
\text { sutampa“ } \\
\text { "Winners } \\
\text { match” }\end{array}$ & $\begin{array}{c}\text { "Nugalètojai } \\
\text { nesutampa“ } \\
\text { "Winners } \\
\text { are divided” }\end{array}$ \\
\hline Didžiụjų miestų / Major cities & 377 & $257(68,17 \%)$ & $120(31,83 \%)$ \\
\hline $\begin{array}{c}\text { Vidutinių miestų (per 5 tūkst. gyv.) } \\
\text { Medium-sized cities (over 5 thousand inhabitants) }\end{array}$ & 263 & $136(51,71 \%)$ & $127(48,29 \%)$ \\
\hline Priemiesčių / Suburbs & 281 & $174(61,92 \%)$ & $107(38,08 \%)$ \\
\hline Mažųjų miestų / Small towns & 53 & $31(58,49 \%)$ & $22(41,51 \%)$ \\
\hline $\begin{array}{c}\text { Miesteliụ ir didesnių gyvenviečių } \\
\text { Townships and bigger villages }\end{array}$ & 322 & $185(57,45 \%)$ & $137(42,55 \%)$ \\
\hline Kaimiškų vietovių / Rural polls & 699 & $426(60,94 \%)$ & $273(39,06 \%)$ \\
\hline Iš viso / Total & 1995 & 1209 & 786 \\
\hline
\end{tabular}

vidutinio dydžio miestų kategorijos rinkimų apylinkemis. Kituose santykinai didesnio PTT populiarumo arealų miestuose (Zarasuose, Dusetose, Mažeikiuose, Šilaleje, Rietave) daugiamandatèje apygardoje PTT sąrašą ir jos remiamus vienmandačių apygardų kandidatus lenke kitos partijos ir jų kandidatai, o PTT populiaresnè išliko tik miestelių ir didesnių gyvenviečių bei kaimiškose rinkimų apylinkèse - visos šalies mastu šiose kategorijose PTT nugalejo nuo 2 iki $4 \%$ rinkimų apylinkių. Didžiuosiuose miestuose, kaip ir DP, PTT buvo visiškai nepopuliari. Apibendrinant galima teigti, kad PTT, kaip ir DP, nèra populiari visų kategorijų miestuose, o daugiatautè Visagino sav. šiuo atveju yra tik reta išimtis.

Pagal rinkimų apylinkių kategorijas apibendrinti tyrimo rezultatai rodo (žr. 2 lentelè), kad santykinai daugiausia rinkimų apylinkių, kuriose ir vienmandatès, ir daugiamandatès apygardos apylinkèse $2016 \mathrm{~m}$. Seimo rinkimų pirmajame ture pirmavo tos pačios partijos kandidatas / sąrašas („nugalètojai sutampa“), nustatyta didžiųjų miestų $(68,17 \%)$ ir priemiesčiu $(61,92 \%)$ kategorijose, o santykinai mažiausia dalis - vidutinių miestų (51,71 \%) kategorijoje. Likusios (kaimiškesnès) rinkimų apylinkių kategorijos užima tarpinę padèti. Šių rezultatų pagrindu nurodyti kokius nors pagrịstus dèsningumus sudètinga, tačiau galima konstatuoti, kad nuosekliausiomis politinemis preferencijomis išsiskiria Lietuvos didmiesčių ir jų priemiesčių gyventojai.

\section{IŠVADOS}

1. Vertinant padalyto balsavimo atvejų sklaidą teritoriniu požiūriu, Lietuvoje labai ryškus centro-periferijos pjūvis. Lietuvos didžiųjų miestų (Vilniaus, Kauno ir Šiaulių) ir jų priemiesčių vienmandatèse rinkimų apygardose pirmajame ture pirmavęs kandidatas ir tose pat apygardose pirmavęs jam atstovaujančios partijos sąrašas sutampa santykinai dažniau nei kaimiškose apygardose (išskyrus kai kuriuos Lietuvos regionus).

2. Nors itin dideleje Lietuvos rinkimų apylinkių dalyje $2016 \mathrm{~m}$. Seimo rinkimuose daugiamandatėje apygardoje daugiausia rinkèjų balsų gavo LVŽS, tačiau vienmandatėse apygardose Seimo rinkimų pirmajame ture šios partijos kandidatams sekèsi prasčiau. Tai rodo, kad partijai stinga geriau žinomų ịtakingų kandidatų. Pergalè antrajame rinkimų ture dažniausiai buvo pasiekta tik LVŽS konsolidavus kitų centro kairiųjų partijų elektoratą.

3. Tradiciškai kai kuriuose Lietuvos savivaldybèse rinkimuose didelę itaką turi žinomos asmenybès, kurių aktyvus dalyvavimas politinejje veikloje lemia juos delegavusių partijų santykinai didesni populiarumą tose pačiose savivaldybèse. 2016 m. rinkimuose tai buvo ryšku tose vienmandatèse rinkimų apygardose, kuriose nugalèjo LRLS, DP ir PTT kandidatai. Tačiau tai nèra būdinga Lietuvos didžiųjų miestų ir jų priemiesčiu rinkimų apylinkèms. 
4. Centro-periferijos geografinis pjūvis yra svarbiausias (išskyrus kai kurias rinkimu apygardas) vertinant ne tik rinkejuc politines preferencijas politinèms jëgoms bei jų remiamiems kandidatams, bet ir rinkèjų politinių preferencijų nuoseklumą atspindintị padalyto balsavimo atvejų dažnumą. Bene geriausiai tai iliustruoja rinkejjų politinès preferencijos TS-LKD. Šiai partijai jos nuosekliausios yra Lietuvos didmiesčiuose - Vilniuje ir Kaune, o rečiau pasitaikančiais padalyto balsavimo atvejais Vilniaus ir Kauno rinkimų apylinkèse rinkejjai santykinai dažniau prioritetą atiduoda TS-LKD daugiamandatès apygardos sąrašui, vienmandateje apygardoje balsuodami už kitos partijos remiamą ar nepriklausomą kandidatą. Ir atvirkščiai - periferijai priskirtinose miestelių ir didesnių gyvenviečių bei kaimiškose rinkimu apylinkèse gerokai dažniau pasitaikančiais padalyto balsavimo atvejais santykinai dažniau prioritetas teikiamas TS-LKD remiamam vienmandatès apygardos kandidatui, daugiamandateje apygardoje balsuojant už kitos partijos (2016 m. - dažniausiai LVŽS) sąrašą.

5. Aiškesnè padalyto balsavimo atvejų skaičiaus priklausomybė nuo rinkimų apylinkès tipo centro-periferijos pjūviu $2016 \mathrm{~m}$. Seimo rinkimuose sietina su rinkejų politinemis preferencijomis TS-LKD, LVŽS ir LSDP. Šių partijų atžvilgiu stebimos gana priešingos tendencijos. TS-LKD padalyto balsavimo dažnis santykinai mažiausias buvo didmiesčių rinkimų apylinkėse, šiek tiek didesnis vidutinių miestų, o didžiausias - periferijai priskiriamose mažųjų miestų, miestelių ir didesnių gyvenviečių bei kaimiškose rinkimų apylinkèse. LVŽS situacija buvo priešinga - padalyto balsavimo atvejų skaičius buvo mažiausias periferijai priskiriamose rinkimų apylinkèse ir išaugo artimesnèse centrinei geografinei padéčiai (išimtis - Šiaulių m., kur padalyto balsavimo atvejų beveik nebuvo). Daugiausia LSDP paramos $2016 \mathrm{~m}$. sulaukè iš kai kurių vidutinių ir mažųjų miestų rinkimų apylinkių.

Gauta 20180206 Priimta 20191106

\section{ŠALTINIAI IR LITERATŪRA}

1. Baranauskaitė A., Burneika D., Tučas R. 2015. Elektorinių struktūrų erdvinè diferenciacija Lietuvos miestų regionuose. Geografijos metraštis. 48: $3-23$.
2. Baranauskaitė A., Tučas R. 2014. Vilniaus miesto elektorinè struktūra 2008 ir $2012 \mathrm{~m}$. Seimo rinkimu duomenimis. Geografijos metraštis. 47: 37-54.

3. Carey J. M., Shugart M. S. 1995. Incentives to cultivate a personal vote: Rank ordering of electoral formulas. Electoral Studies. 14(4): 417-439.

4. Ferrara F., Herron E., Nishikawa M. 2005. Mixed Electoral Systems. Contamination and Its Consequences. New York: Palgrave Macmillan US.

5. Jacoby W. G. 2009. Ideology and vote choice in the 2004 election. Electoral Studies. 28: 584-594.

6. Jastramskis M. 2018a. Ar turime gerą ir prognozuojamą rinkimų sistemą? Kn.: M. Jastramskis ir kt. (red.). Ar galime prognozuoti Seimo rinkimus? Triju kūnu problema Lietuvos politikoje. Vilnius: Vilniaus universiteto leidykla. 229-252.

7. Jastramskis M. 2018b. Kaip paaiškinti antrąi turą? Rinkimų sistemos sąveika su pasiūla ir paklausa. Kn.: M. Jastramskis ir kt. (red.). Ar galime prognozuoti Seimo rinkimus? Triju kūnu problema Lietuvos politikoje. Vilnius: Vilniaus universiteto leidykla. 255-308.

8. Jastramskis M. 2018c. Išvados. Kaip pagerinti rinkimu prognozes? Kn.: M. Jastramskis ir kt. (red.). Ar galime prognozuoti Seimo rinkimus? Trijų kūnu problema Lietuvos politikoje. Vilnius: Vilniaus universiteto leidykla. 311-334.

9. Jurkynas M. 2004. Emerging cleavages in new democracies: The case of Lithuania. Journal of Baltic Studies. 35(3): 278-296.

10. Jurkynas M. 2009. The parliamentary election in Lithuania, October 2008. Electoral Studies. 28(2): 329-333.

11. Krupavičius A., Pogorelis R. 2004. Rinkimu sistema ir rinkimai. Kn.: A. Krupavičius, A. Lukošaitis (sud.). Lietuvos politine sistema: saranga ir raida. Kaunas: Poligrafija ir informatika. 243-295.

12. Lietuvos Respublikos Seimo rinkimu istatymas. Suvestine redakcija nuo 2019-07-01 iki 2019-0731. 2019. https://www.e-tar.lt/portal/lt/legalAct/ TAR.06267D86738E/asr (žiūrèta 201908 09).

13. Lietuvos Respublikos Vyriausioji rinkimų komisija. 2018. Rinkimai ir referendumai. https://www. vrk.lt/rinkimai (žiūrèta 201802 20).

14. Lijphart A. 1968. Typologies of democratics systems. Comparative Political Studies. 1(1): 3-44.

15. Lipset S. M., Rokkan S. 1967. Cleavage structures, party systems and voter alignments. In: S. M. Lipset, S. Rokkan (eds.). Party Systems and Voter Alignments: Cross-National Perspectives. New York: Free Press.

16. Maeda K. 2008. Re-examining the contamination effect of Japan's mixed electoral system using the treatment-effects model. Electoral Studies. 27(4): 723-731.

17. Morkevičius V. 2017. Padalytas balsavimas 19962016 m. Seimo rinkimuose: mastas ir pobūdis. Politologija. 88(4): 105-141. 
18. Morkevičius V. 2018. Padalytas balsavimas Seimo rinkimuose: Lietuvos rinkejjas mègsta „dienos pietus" ar renkasi iš viso meniu? Kn.: M. Jastramskis ir kt. (red.). Ar galime prognozuoti Seimo rinkimus? Triju kūnu problema Lietuvos politikoje. Vilnius: Vilniaus universiteto leidykla. 281-308.

19. Oliver J. E., Ha S. E. 2007. Vote choice in suburban elections. American Political Science Review. 101(3): 393-408.

20. Plescia C. 2016. Split-Ticket Voting in MixedMember Electoral Systems: A Theoretical and Methodological Investigation. Colchester: ECPR Press.

21. Ramonaitè A. 2007. Posovietines Lietuvos politine anatomija. Vilnius: Versus Aureus.

22. Ramonaitė A. 2014. Kaip žmonès renkasi už ką balsuoti? Pasirinkimo logika ir partinè tapatybè. Kn.: A. Ramonaite (red.). Kaip renkasi Lietuvos rinkèjai? Idejos, interesai ir ịvaizdžiai politikoje. Vilnius: Vilniaus universiteto leidykla. 45-64.

23. Ramonaitè A. 2018. Socialinè rinkejuc tapatybė ir partijų pasirinkimas: ar yra vietos skirčių politikai Lietuvoje? Kn.: M. Jastramskis ir kt. (red.). Ar galime prognozuoti Seimo rinkimus? Trijų kūnų proble- ma Lietuvos politikoje. Vilnius: Vilniaus universiteto leidykla. 73-96.

24. Ramonaitè A., Jastramskis M. 2014a. Iš ko renkasi rinkejjai? Lietuvos partinès konkurencijos struktūra. Kn.: A. Ramonaitè (red.). Kaip renkasi Lietuvos rinkèjai? Idejos, interesai ir ivaizdžiai politikoje. Vilnius: Vilniaus universiteto leidykla. 126-144.

25. Ramonaitè A., Jastramskis M. 2014b. Vertybès ir ìsitikinimų struktūros. Pasirinkimo logika ir partinè tapatybė. Kn.: A. Ramonaite (red.). Kaip renkasi Lietuvos rinkejjai? Idejos, interesai ir ịvaizdžiai politikoje. Vilnius: Vilniaus universiteto leidykla. 126-144.

26. Sartori G. 2001. Lyginamoji konstitucinè inžinerija. Struktūrų, paskaitu ir rezultatų tyrimas. Kaunas: Poligrafija ir informatika.

27. Savickaitė I., Krupickaitė D., Tučas R. 2013. Gyventojų rinkiminès elgsenos kaita Vilniaus suburbanizacijos zonoje. Geografijos metraštis. 46: 72-94.

28. Vikšraitienè A. 2018. Asmenybinio ir partinio balsavimo teritorine diferenciacija Lietuvoje: magistro darbas. Vilnius: VU. 


\section{Akvilè Vikšraitienè, Rolandas Tučas \\ TERRITORIAL DIFFERENTIATION OF PERSONAL AND PARTY VOTING RATIO IN THE 2012 AND 2016 ELECTIONS TO THE SEIMAS OF LITHUANIA}

\section{Sum mary}

The purpose of this article is to analyze the personal and party voting ratio in Lithuania. In this research, the authors used the data from the 2012 and 2016 elections to the Seimas. The research examines elections results in single-member constituencies and polling districts. The article focuses on two main aspects: 1) a comparative geographical analysis of the 2012 and 2016 elections to the Seimas of the Republic of Lithuania, which investigated regional aspects of changing popularity of political parties and candidates, and 2) the authors investigated split-ticket voting according to the core-periphery model on the basis of the 2016 election results to the Seimas in the electoral districts. After the evaluation of the ratio of personal and party voting, it was found that the core-periphery model was quite pronounced in Lithuania. In the single-member constituencies of the major cities of Lithuania (Vilnius, Kaunas and Šiauliai), the winner of the 1st round and the list of the winning party that represented the winner in the same constituencies coincided relatively more frequently than in rural districts (except for some regions of Lithuania). Moreover, prominent society figures, who were actively involved in political activities, had a significant influence in the elections in some municipalities, which resulted in a higher popularity of those parties that delegated them in the same municipalities (contamination effect). The influence of prominent people was noticeable in the elections of 2016, particu- larly it was evident in the single-member constituencies where LRLS, DP and PPT candidates won. However, such a situation is not typical of the polling districts of Lithuania's major cities and suburbs. Although in a very large part of Lithuanian polling districts, The Lithuanian Union of Peasants and Greens (LVŽS) won in the 2016 parliamentary elections in the multi-member constituency, however in the 1st round voting where the election was held in the single-member constituencies, their results were worse. Such elections results indicate that the party lacks more prominent influential candidates. The victory in the 2 nd round was mostly achieved only by LVŽS consolidating the electorate of other centre-left parties. A clearer dependence of the number of cases of split-ticket voting on the type of constituency by central-peripheral cleavage in the Seimas elections in 2016 is attributed to the elector's political preferences to TS-LKS, LVŽS and LSPD political parties. However, different trends are observed for these political parties. In the case of TS-LKD, the frequency of split-ticket voting was relatively low in polling districts of big cities, a little bit higher in medium cities and the highest in peripheral polling districts consisting of smaller cities, towns and rural polling districts. On the contrary, the LVŽS situation was different - the number of cases of split-ticket voting was the lowest in peripheral polling districts and increased in those polling districts which are more central geographically (the exception is Šiauliai city where divided voting was pretty much non-existent). Polling districts of small and medium cities relatively often remained as the main support base for the LSDP in 2016.

Keywords: electoral geography, Seimas election, split-ticket voting, vote-splitting, contamination effect, majoritarian voting, proportional representation 